\title{
Connessioni tra terra e cielo. Forma e immagine nel racconto delle qualità intangibili di uno spazio urbano
}

\author{
Antonella Salucci \\ Donatella Petrillo
}

\section{Abstract}

I| contributo presenta gli esiti di una ricerca sulla rappresentazione del patrimonio culturale intangibile con specifico riferimento al centro storico della città di Viterbo (Lazio, Italy) che nel tradizionale evento dei festeggiamenti per la celebrazione della Patrona della città mette in scena un complesso sistema di relazioni, sia spaziali che emotive, che è interessante documentare in quanto tra le più note espressioni culturali della tradizione italiana.

In linea con gli obiettivi della presente trattazione si propone la narrazione delle 'connessioni tra terra e cielo' che si instaurano tra la città e i suoi abitanti, con l'evento del trasporto di una struttura processionale a spalla, che ha ottenuto il riconoscimento UNESCO dal 20 I3: evento effimero collettivo in cui suoni, luci, folla e coinvolgimento emotivo compongono un affascinante sistema di interazioni. II vasto lavoro degli storici sul tema consente di delineare un quadro preliminare funzionale alla osservazione critica e alla narrazione della vicenda in oggetto condotta secondo due principali sfere elaborative, sostenute dai linguaggi del Disegno e della Fotografia: racconto della modificazione delle spazialità urbane e del coinvolgimento emotivo; campionamento, classificazione e catalogazione dei documenti grafici, iconografici testuali; processo di rilevamento delle quinte urbane, analisi critica ed elaborativa dei dati. Alcune delle immagini che corrono in parallelo al testo testimoniano il percorso di indagine.

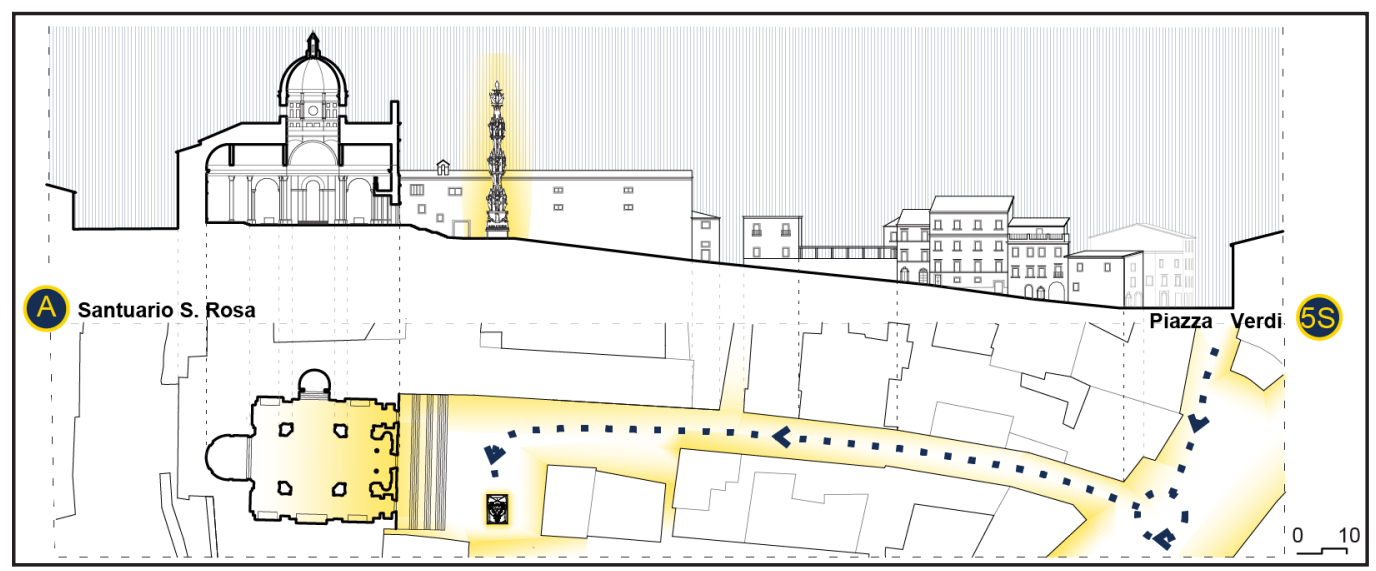




\section{Premessa. Connessioni tra cielo e terra. Per una metodologia di indagine delle qualità intangibili di uno spazio urbano}

Il contributo propone lo stato di avanzamento di un lungo processo di studio, che coinvolge diversi studiosi dell'area del Disegno, che riguarda sia i processi di rilevamento e di documentazione, sia i linguaggi del Disegno e della Fotografia, per la rappresentazione dei patrimoni architettonici e culturali immateriali.

Suggerisce alcune chiavi di lettura delle qualità immateriali di un paesaggio urbano storico durante la tradizionale Festa di Santa Rosa da Viterbo (Lazio, Italia), che da secoli coinvolge in un complesso sistema di rituali devozionali una intera comunità.

Racconta alcune qualità di una città, con le sue strade e le sue piazze storiche. Invasi che si connotano come spazi di confine e di limite di un set urbano. Sorta di quinte sceniche che, nel tempo della festa, si trasformano rivelandosi porose e sensibili al passaggio di un sorprendente apparato effimero in processione: mutevole, cangiante, magnifico.

Dal punto di vista metodologico l'integrazione dei linguaggi della rappresentazione, Disegno e Fotografia, agevola la lettura delle interazioni tra gli spazi urbani e un patrimonio culturale intangibile della tradizione italiana. II linguaggio del Disegno, attraverso il rilevamento architettonico di alcuni brani del centro storico, narra le metamorfosi dei luoghi della città attraversati dalla festa; al linguaggio della fotografia è affidato il rilevamento del coinvolgimento emotivo, attraverso la documentazione fotografica autoriale dell'evento 'live'.

Si è voluto esaminare e rappresentare lo spazio condiviso, ovvero il luogo dove va in scena la connessione, lo spazio tra le persone, tra le cose, tra i luoghi.

Da una parte c'è la folla, il pubblico, la città e le sue piazze; dall'altra c'è il cielo notturno, che è al tempo stesso fondale scenico e protagonista dell'evento. Il punto d'incontro è rappresentato dall'apparato-processionale, la macchina in transito, metaforico elemento di connessione tra terra e cielo.

Il lavoro di analisi, lettura e comunicazione - che si fonda sull'ampio lavoro degli storici sul tema - è strutturato in tre parti.

La prima parte, sintetizza la collocazione italiana all'interno del sistema dei Patrimoni Intangibili UNESCO: ilTrasporto della Macchina di Santa Rosa rientra nelle 'Rete delle Macchine a Spalla', che dal 2013 fa parte della Lista Rappresentativa dei Patrimoni Intangibili ICH UNESCO.

La seconda parte, riguarda la lettura degli spazi urbani interessati dalle ritualità connesse con la performance-urbana del trasporto processionale:

- rilevamento dei fronti urbani che costeggiano il percorso processionale della Macchina;

- analisi della processione del 'Giro delle Sette Chiese', compiuto dai 'portatori' nelle ore che precedono il transito vero e proprio della Macchina di Santa Rosa;

- rilevamento architettonico del Tempio della Santa, disegnato nel suo stato attuale da uno dei maestri della Scuola Romana, Arnaldo Foschini;

- rilevamento d'archivio dei disegni di progetto originali della Macchina conservati al Museo Civico di Viterbo che hanno reso possibile la codifica delle gerarchia dei 'facchini' che, insieme alla folla, sono protagonisti dell'evento.

La terza parte riguarda il racconto del coinvolgimento emotivo che direttamente abbiamo sperimentato, cercando un'efficace modalità di narrazione.

\section{La Rete UNESCO delle strutture processionali Italiane}

II progetto della Rete delle Grandi Macchine a Spalla, che nel 2013 ottiene il riconoscimento UNESCO, viene avviato nel 2005 tra cinque comunità italiane, Viterbo, Nola, Palmi, Sassari e Gubbio; quest'ultima con i propri Ceri [Belardi 20II] presenterà la propria candidatura in autonomia. Le comunità hanno in comune il rituale collettivo della processione celebrativa del trasporto di grandi macchine a spalla come manifesto dell'identità dei luoghi di appartenenza [Nardi 2014 pp. 83-96] (fig. I).

La Festa dei Gigli di Nola (Campania, 22 giugno), consiste nel trasporto diurno dei Ceri, 8 torri di legno alte 25 metri, per un peso di 25 quintali, trasportati da 120 uomini, detti cullatori. 
Fig. I. Lista Rappresentativa del Patrimonio $\mathrm{ICH}$ italiano. II "Patrimonio Culturale Immateriale" tramite le categie tranite le categorie della candidatura UNESCO. evidenziano le città della chine Spalla Italiane": chine a Spalla Italiane" la Festa dei Gigli di Nola (Napoli) - Campania; la Faradda di li Candareri di Sassari - Sardegna; la Varia di Palmi (Reggio Calabria) - Calabria; la Macchina di Santa Rosa a Viterbo - Lazio http://www.unesco.it/ it/Documenti/Detail// 80 - accessed 2020-01-14 (elaborazione A. Salucci, D. Petrillo).
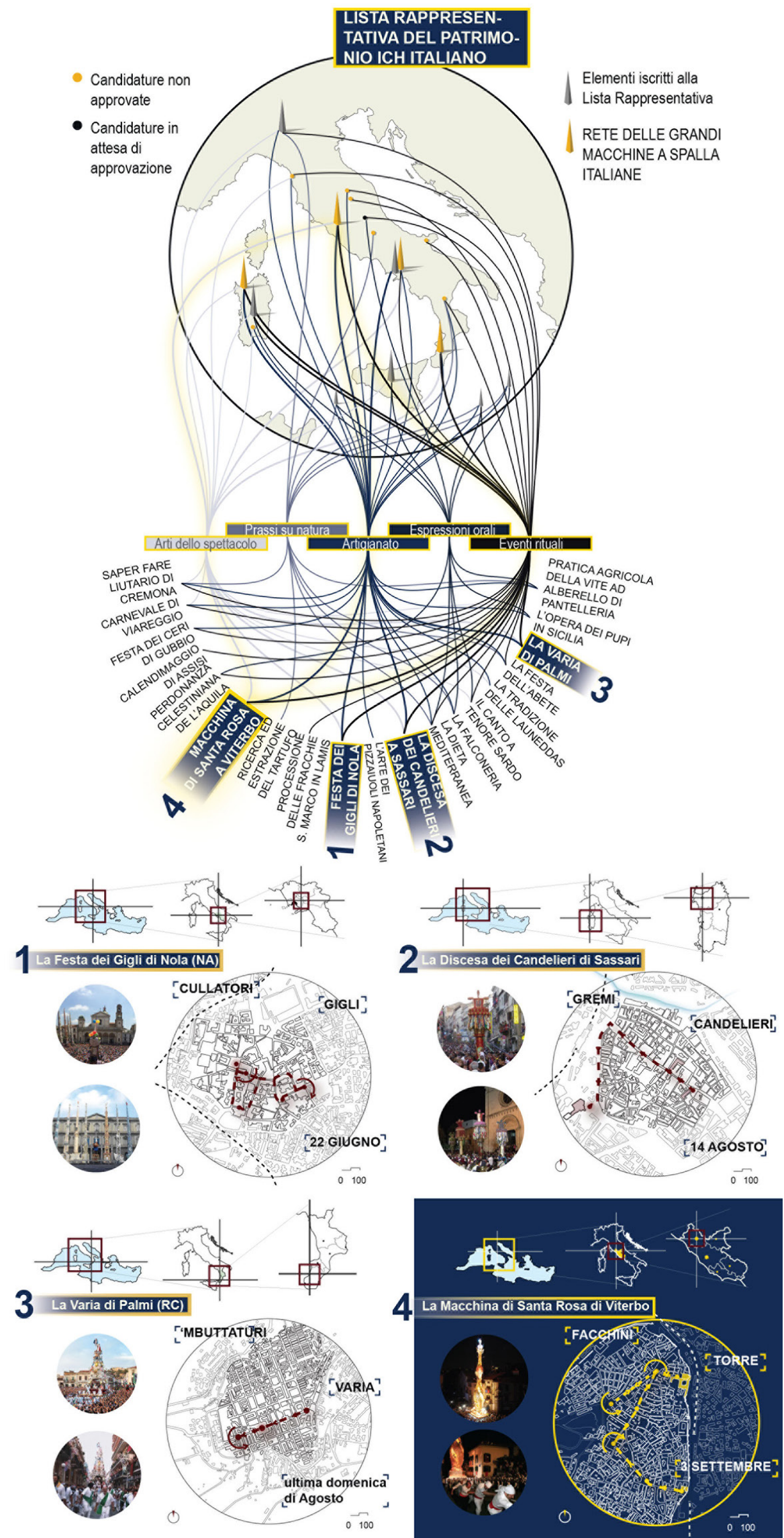
La Discesa dei Candelieri di Sassari (Sardegna, 14 agosto), consiste nel trasporto diurno dei Candelieri, enormi ceri lignei, dal peso di circa 4 quintali, di forma cilindrica, trasportati a spalla da 8 portatori, riuniti in associazioni di mestiere dette Gremi.

La Festa della Varia di Palmi (Calabria, agosto) consiste nel trasporto diurno di un grande carro scenico votivo a forma di nuvola, alto 16 metri e pesante 200 quintali; trasportatori, riuniti in corporazioni, sono detti mbuttaturi.

La Festa di Santa Rosa da Viterbo (Lazio, 3 settembre) consiste nel trasporto notturno di una grande mole luminosa, 28 metri per 50 quintali di peso, trasportata a spalla da circa I20 portatori, detti Facchini. II percorso è lungo pressappoco I,2 km e si svolge nell'arco di 3 ore circa [Falcioni $200 \mathrm{I}$ ]. Per il progetto viene ogni cinque anni bandito un concorso pubblico [Parlato 2002; Salucci 2016;2018].

Fig. 2. Rilevamento e analisi dei luoghi della festa. Viterbo, centro storico. Abaco degli attraversamenti. Rilievo degli spazi urbani di sosta e transito interessati dal Trasporto della Macchina di Santa Rosa (elaborazione A. Salucci, D. Petrillo)

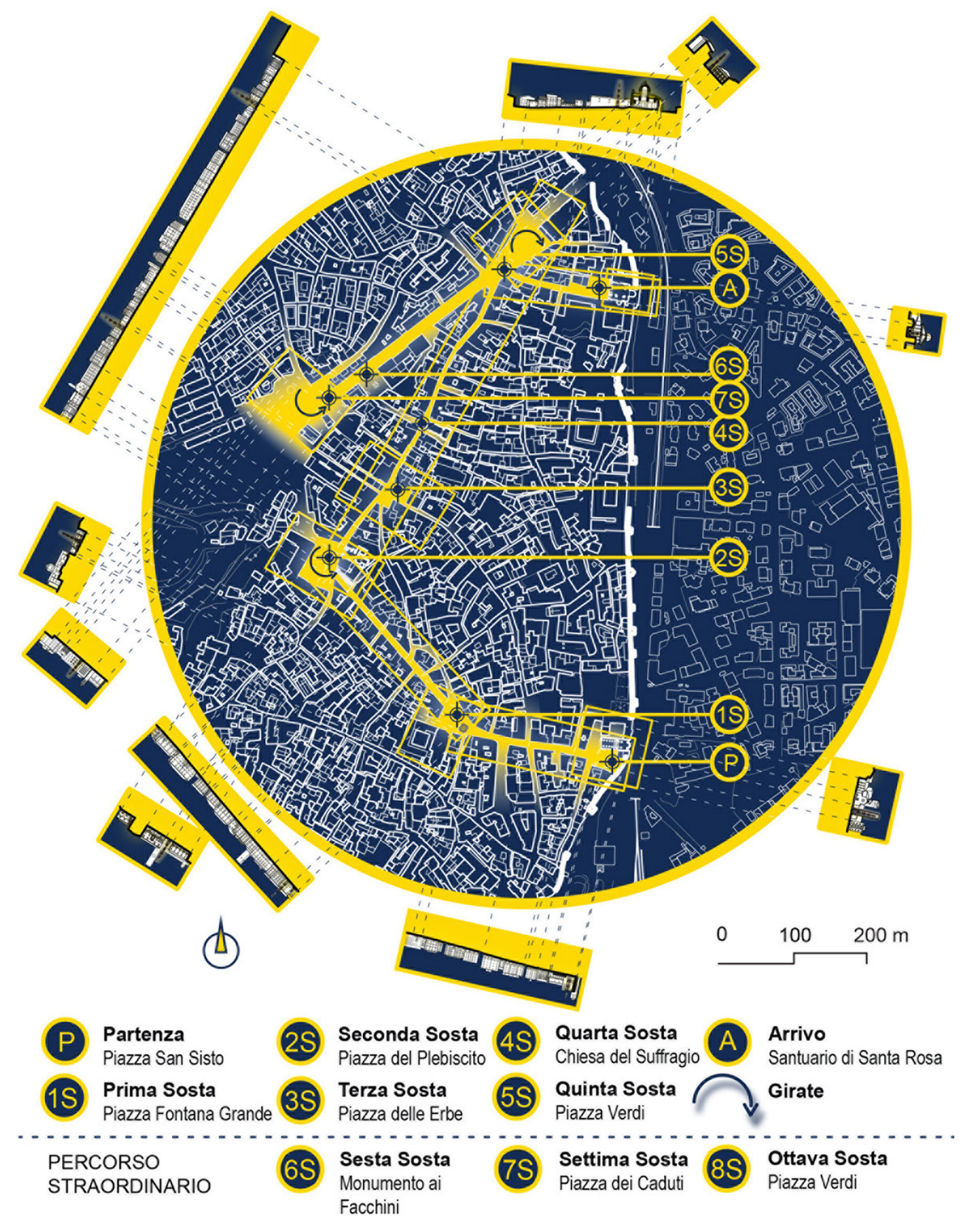




\section{Lo spazio urbano dell'evento}

Posta lungo la via Francigena, Viterbo divenne centro politico europeo quando il pontefice Alessandro IV (|254-|26|) decide di portare in città la Curia papale in occasione del primo Conclave della storia; con essa si trasferirono a Viterbo tutte le più grandi famiglie della nobiltà romana, tra le quali i Farnese. II percorso del Trasporto, che nei secoli ha subito trasformazioni significative, è legato allo sviluppo urbano e alle vicende politiche della città. Per un'agevole lettura di questo evento - in riferimento all'interferenza che l'oggetto del Trasporto ha rispetto alle spazialità urbane attraversate - abbiamo finalizzato le procedure di rilevamento a due principali categorie di osservazione: da un lato sono state rappresentate le 'Soste' e dall'altro il 'Transiti' del percorso processionale, privilegiando nella lettura la rappresentazione in proiezione parallela secondo piani mongiani finalizzata alla accurata descrizione delle quinte urbane interessate dal passaggio della 'mole luminosa' (fig. 2).

Fig. 3. Rilevamento e analisi dei luoghi della festa. Viterbo, centro storico. Le Soste. Rilievo delle Soste processional (vedi fig. 02). Le Piazze storiche della città diventano teatro de momenti più sentiti del trasporto. Le Soste sono nol netto nel caso di trasporti stra nelini caso Piazza San Sisto: Piazz Plazza San Sisto; Plazza Fontana Grande; Piazz del Plebiscito, Piazza dell'Erbe; Chiesa di Santa Maria del Suffragio; Piazza Verdi; Santuario di Santa Rosa (elaborazione A. Salucci, D. Petrillo).
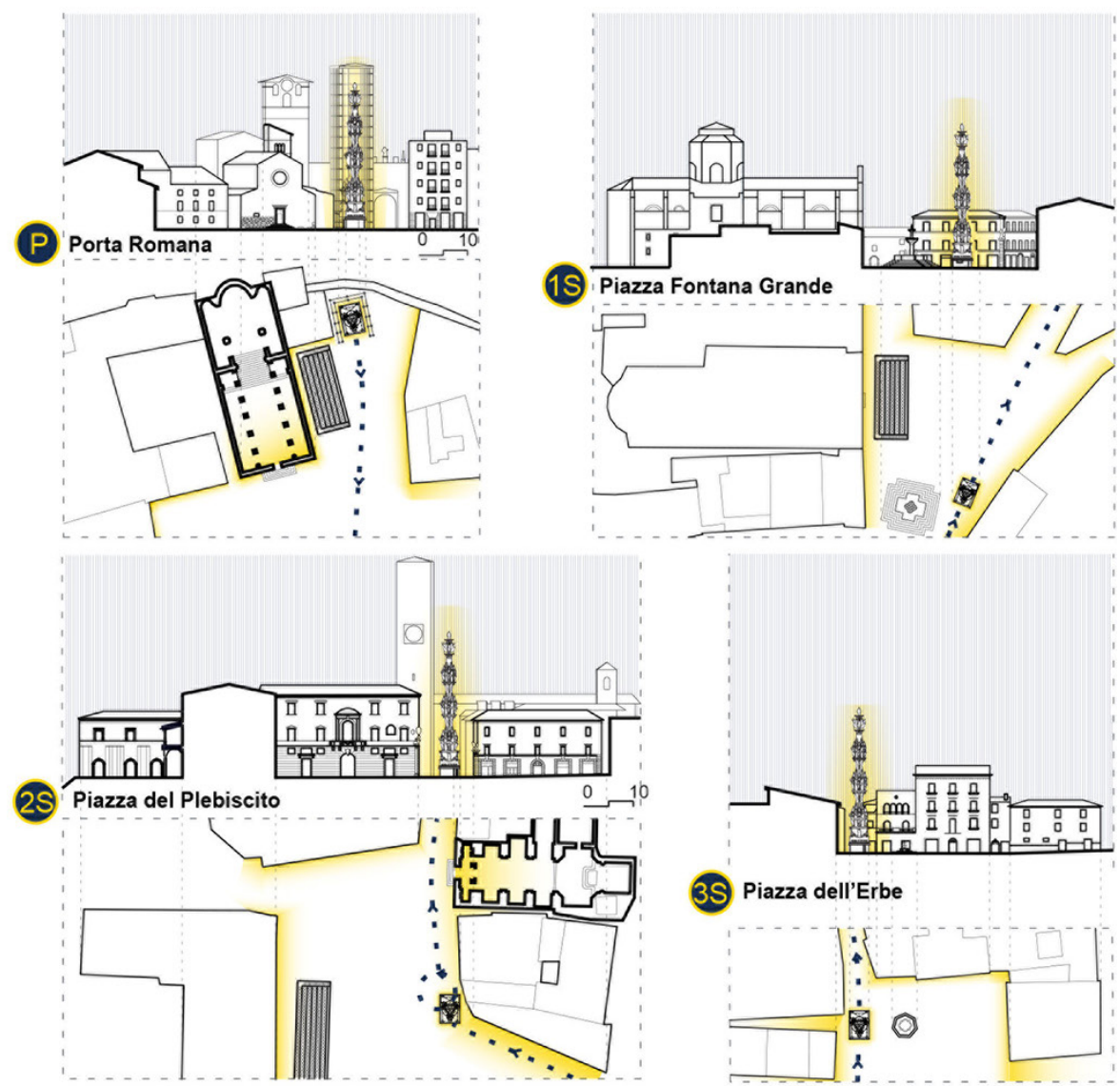

3S Piazza dell'Erbe
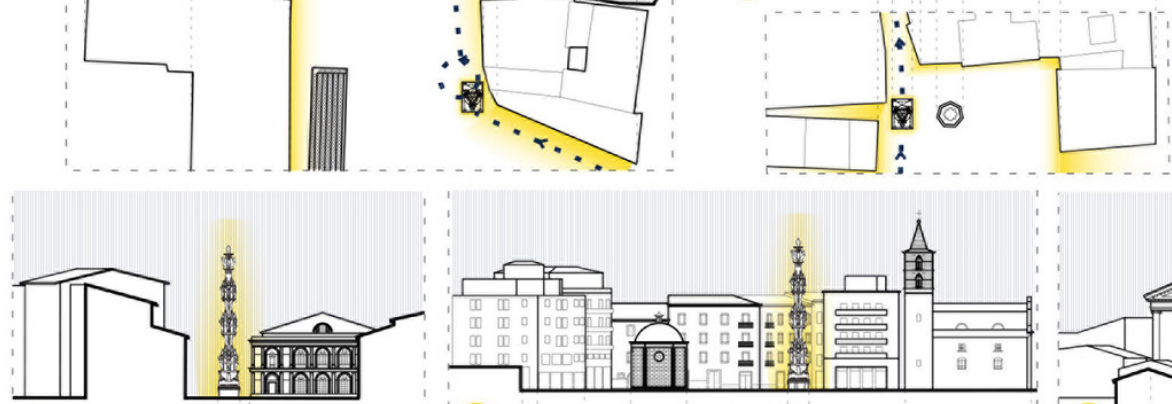

$5 S$ Piazza Verdi
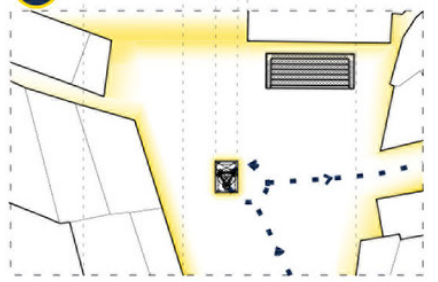

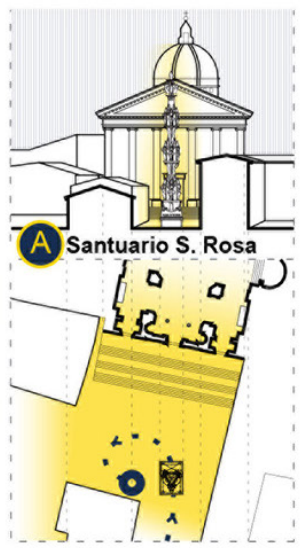


Fig. 4. Rilevamento e analisi dei luoghi della esta.Viterbo, centro storico. I Transiti. Rilievo del Transiti processionali (vedi fig. 2), ovvero delle quinte urbane interessate dal Trasporto. Le facciate dei palazzi che si affacciano su percorso della Macch o sul enono inondate dalla ver luce che questa proietta: (da Piazza San Sisto a da Plazza San Sisto a Piazza Fontana Grande); via Cavour (da Plazza ontana Grande a Plazza del Plebiscito); Corso Italia (da Piazza del Plebiscito a Piazza Verdi); via Santa Rosa (da Piazza Verdi al Sagrato del Santuario di Santa Rosa) (elaborazione A. Salucci, D. Petrillo).
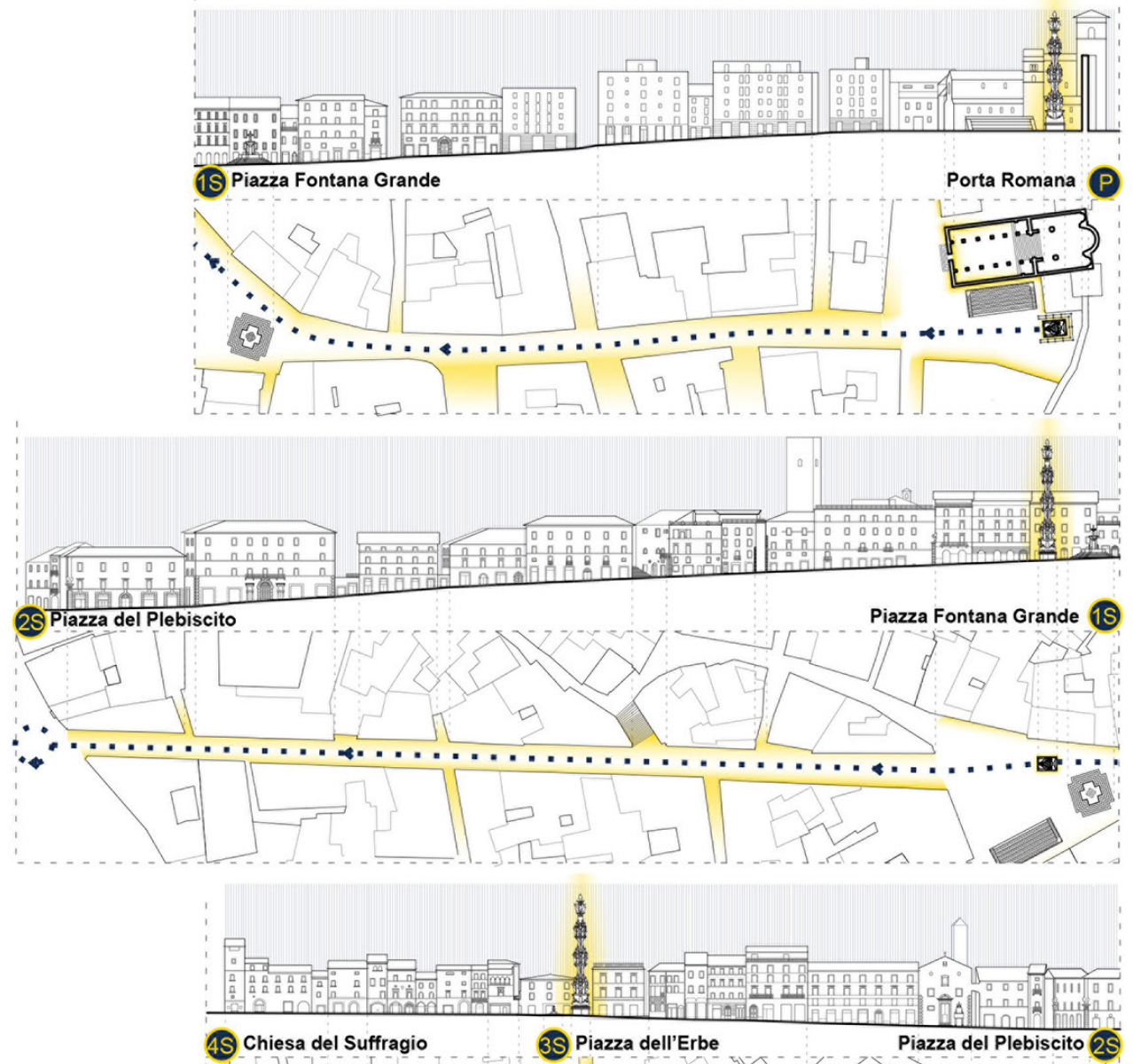

4S Chiesa del Suffragio

3S Piazza dell'Erbe

Piazza del Plebiscito 25
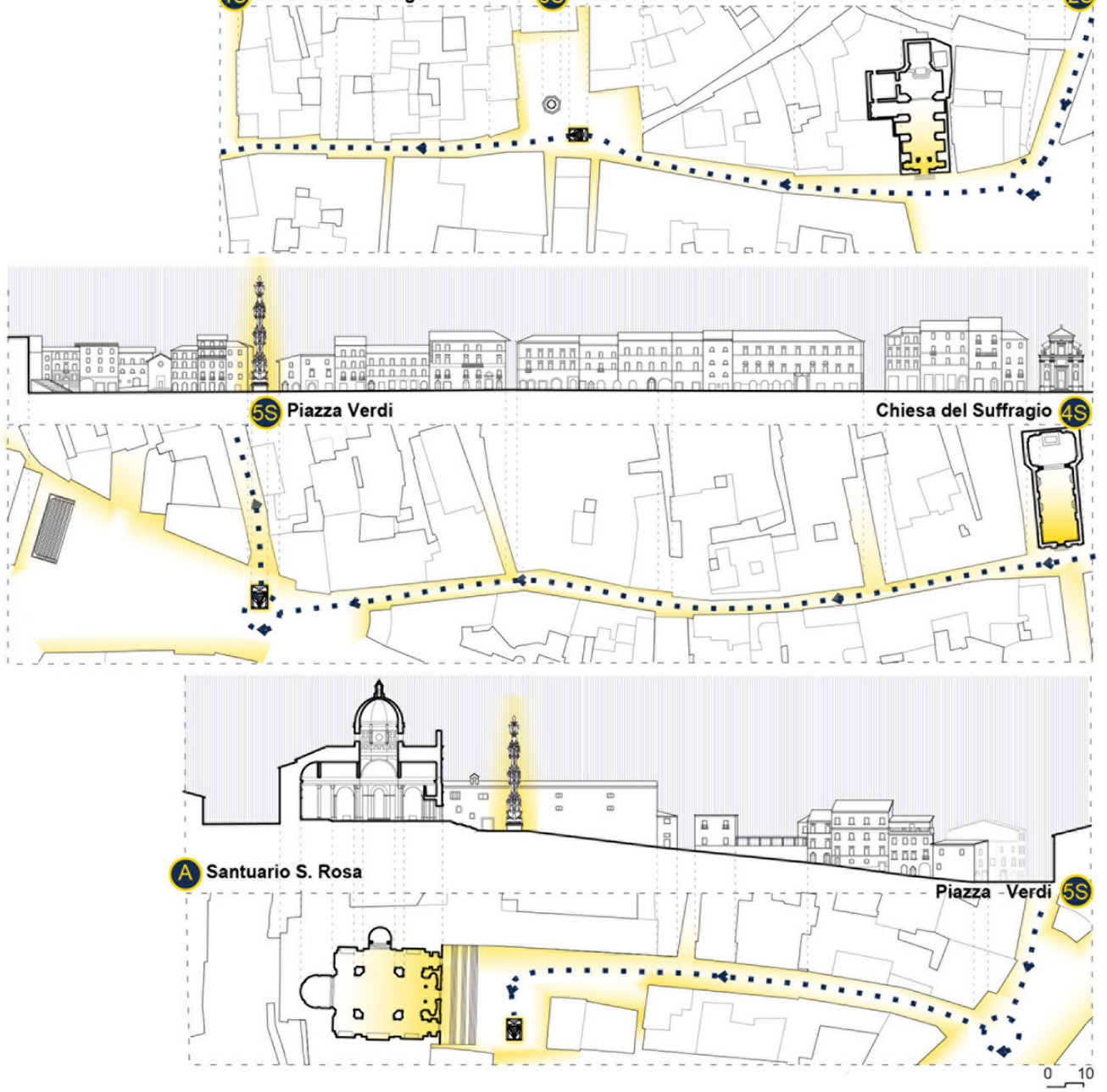
Le Soste del percorso urbano della Macchina di Santa Rosa (fig. 3) sono nel numero di sette, otto nel caso di trasporti straordinari; inoltre in alcune occasioni la mole effettua un giro attorno a se stessa, la 'girata', per consentire la visione di ogni suo lato alla folla [Salucci 2016;2018].

Le sezioni trasversali di questi invasi urbani raccontano la sosta della Macchina durante il suo trasporto e sottolineano alcuni dei momenti più importanti dell'evento.

La struttura luminosa si ferma nelle piazze storiche della città: se da un lato questa interruzione permette ai Facchini di riposare, dall'altro permette ai cittadini, ai fedeli e ai turisti raccolti in una folla magmatica in attesa - di apprezzare durante la pausa, il grande impatto visivo della struttura e di alimentare l'empatia, il fervore religioso, l'emotività collettiva.

In tale direzione, sin dal mese precedente al trasporto, la città si prepara all'evento assistendo, in Piazza San Sisto, al montaggio di un ponteggio all'interno del quale viene assemblata la Macchina, la cui immagine è celata allo sguardo dei fedeli fino al giorno del trasporto (fig. 3). I Transiti (fig. 4) sono descritti dalle sezioni longitudinali degli assi urbani interessati dal passaggio della Macchina. II rilievo delle quinte urbane illuminate dalla luce emanata dalla mole di passaggio, sottolinea una simbologia importante, legata all'affermazione al potere della famiglia Farnese.

II rituale del Trasporto è preceduto da diversi eventi di preparazione a quello principale: uno dei più importanti è il cosiddetto Giro delle Sette Chiese, (fig. 5) che i 'trasportatori', i I 20 facchini, compiono in formazione, seguiti dalla folla dei fedeli, per prepararsi emotivamente all'evento, visitando alcune delle più importanti Chiese della città nel primo pomeriggio del 3 Settembre: Duomo di San Lorenzo, Chiesa di Santa Giacinta, Chiesa di Santa Maria Nuova, Chiesa di Sant'Angelo, Chiesa della Trinità, Basilica di San Francesco alla Rocca; Convento dei Cappuccini; Tempio di Santa Rosa, Chiesa di San Sisto (fig. I0). Si tratta di un antico rituale di grande effetto, ricco di 'riti nel rito', gesti, simboli e tradizioni risalenti ai primissimi trasporti. L'attuale Tempio di Santa Rosa è stato costruito su un edificio precedente risalente al I632, ed è annesso al convento delle Clarisse [Bentivoglio 20 I 6;Valtieri 20 I7]. L'ingegnere Vincen-

Fig. 5. Viterbo, centro storico. II Giro delle Sette Chiese. Schema planimetrico. II rituale di preparazione spirituale dei portatori è un evento nell'evento molto atteso dai cittadini, e prevede che poche che, poche ora prima del Trasporto, i Facchini si miniscano davanti al Duomo di San Lorenzo per poi visitare i luogh simbolici della città di Viterbo in formazione: Duomo di San Lorenzo, Chiesa di Santa Giacinta, Santa Maria Nuova, Chiesa di Sant'Angelo, Chiesa della Trinità, Basilica di San Francesco alla Rocca, Tempio di Santa Rosa, San Sisto (elaborazione A. Salucci, D. Petrillo).

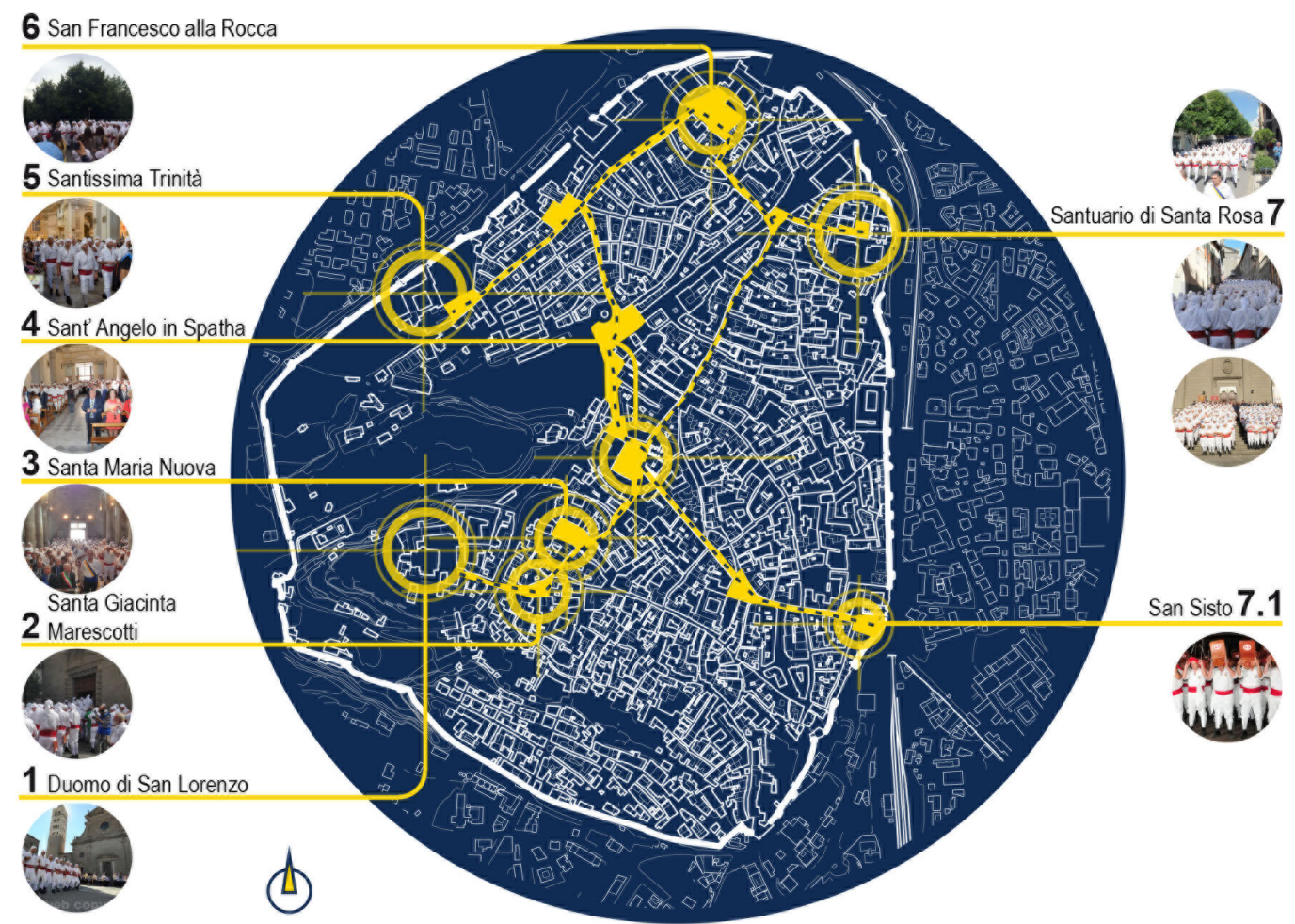


zo Federici, nel 1844, si occupò della facciata. Nel 1908 venne istituito un Concorso, vinto dal giovane Arnaldo Foschini ( 1884 - 1968), architetto di Scuola Romana. II progetto fu realizzato cominciando dalla cupola in cemento armato, che fu poi l'unica parte del progetto di Foschini ad essere effettivamente realizzata [Bentivoglio 20 I 7] Per quanto attiene la presente trattazione è stato condotto un rilevamento - integrando metodologie dirette, indirette e strumentali - dell'edificio che ha reso possibile l'elaborazione di una sezione orizzontale e due sezioni verticali, longitudinale e trasversale (fig. 6).

Un'importante raccolta di disegni di progetto originali della Macchina di Santa Rosa è conservata presso il Museo Civico di Viterbo con numero di inventario n. I39/1915. II primo disegno conservato risale al 1690. Su questi preziosi supporti in carta è possibile osservare l'evolversi della Macchina negli anni fino ai primi del secolo scorso, da baldacchino barocco a guglia gotica, assumendo altezze sempre più elevate e stili via via più moderni [Parlato 2002; Salucci 20l8] (figg. 7, 8).

Lo spettacolo della Festa della Macchina di Viterbo è garantito dalla collaborazione e dalla condivisione di saperi messi in atto da una serie di figure: oltre ai progettisti della Macchina, assumono grande importanza per la riuscita dell'evento il costruttore, le maestranze e i Facchini, riuniti in un Sodalizio dal 1978. La selezione dei nuovi facchini attraverso 'la prova di portata' fa parte degli eventi che precedono il trasporto: uno dei più attesi (fig. 8).

\section{La città come spettacolo e il rilevamento del coinvolgimento emotivo}

Si è cercato, con questa breve trattazione, di dare una sintetica lettura di un rituale complesso, della nostra tradizione, che richiede un'approccio multidisciplinare e soprattutto una partecipazione diretta. Un riferimento in tale direzione la sezione 'Monditalia' della Biennale di Venezia del 2014, curata da Rem Koolhass, che propose un percorso espositivo composto di ibridazioni multidisciplinari inteso inteso come rappresentazione di una cultura plurale, in cui materiale e immateriale sono mutevoli caratteri sempre presenti nell'opera. [Koolhass 20I4].

Fig. 6. Viterbo, centro storico. II Tempio di Santa sosta, la Chiesa dedicata sosta, la Chiesa dedicata alla Santa e il suo sagrato, cuore del trasporto: il Trasporto si conclude qui, depositata dai Facchini depositata dai Facchin e lasciata in esposizione nei giorni seguenti per i devoti che si recano a Viterbo. II progetto dell' architetto Arnaldo Foschini prevedeva una cupola ottagonale, ispirata a quella di Santa Maria del Fiore del Brunelleschi, che poggia su un ampio tamburo, elevato su pennacchi a ventaglio (elaborazione A. Salucci, D. Petrillo)

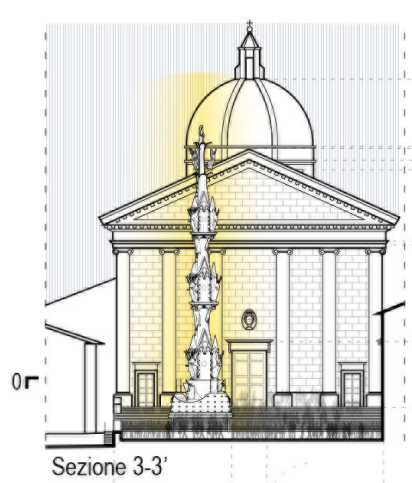

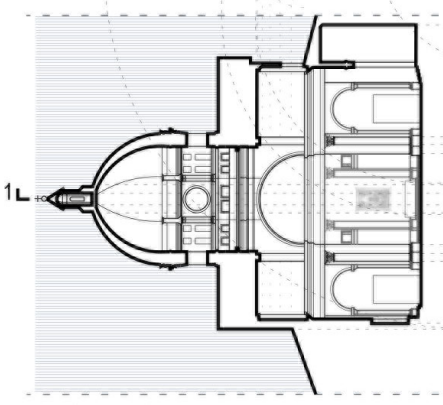

Sezione 2-2
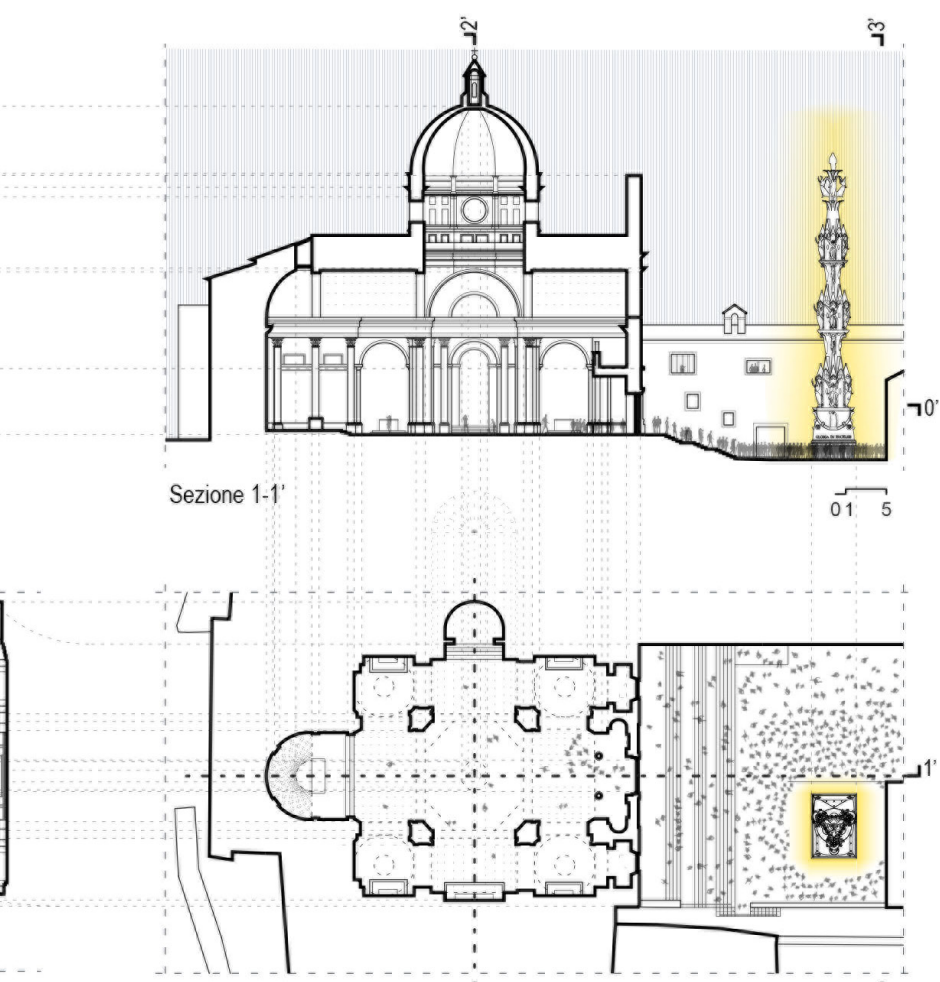

Sezione 1-1

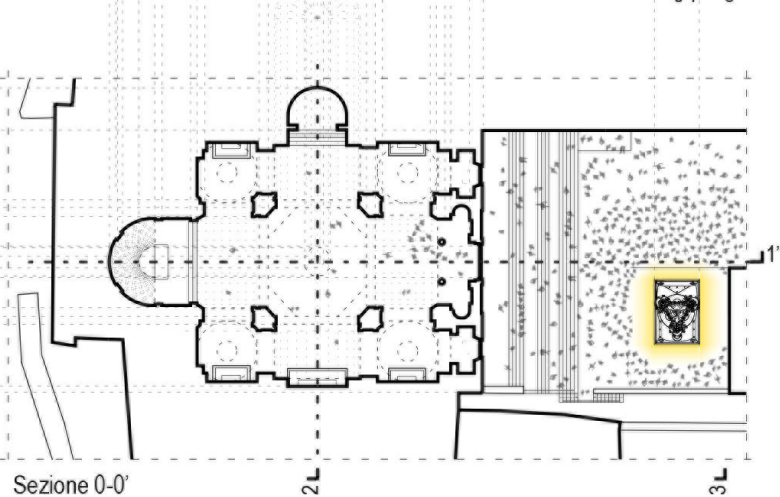


Nel caleidoscopico susseguirsi di immagini, luci, suoni e colori della Festa Patronale di Viterbo, lo spettatore partecipa all'evento facendosi trascinare nel delirio visivo ed emozionale che gli si para davanti, subendo il fascino di un evento che, dopo secoli di ritualità e tradizioni ripetute metodicamente, è ancora in grado di suscitare meraviglia e stupore [Trione 2014; Salucci 20।8] (fig. 9).

Una installazione che avanza oltre le masse, che si configura come interfaccia e come elemento di mediazione, di condivisione, tra la città e i suoi abitanti.

Le quinte urbane che compongono la scena dell'evento processionale, sono state ricostruite sulla base di un progetto di rilevamento condotto integrando metodologie di rilevamento diretto indiretto, utilizzando tecnologie di acquisizione e visualizzazione che consentissero procedure structure-from-motion - fotocamera reflex, smartphone e drone. Tali procedure, come è noto, generano con una certa accuratezza nuvole di punti da immagini digitali prodotte da fotocamere 'mobile-and-low-cost', affidando la scrittura dell'informazione alla

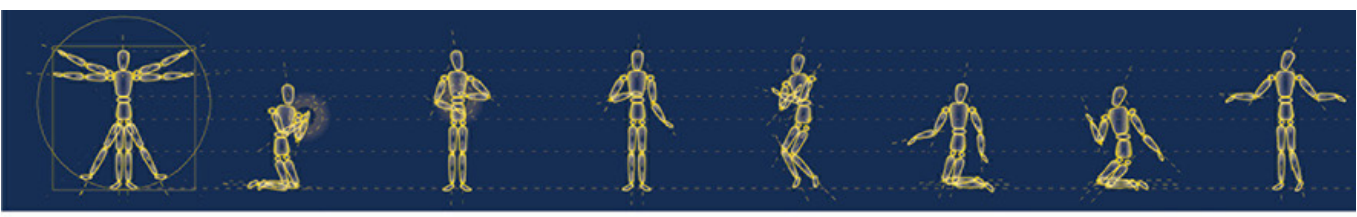

Fig. 7.Viterbo, il culto della Santa e i disegni di progetto della Macchina. Abaco di studio. Dalla agiografia della Santa $e$ dalla sua rappresentazione sulle Macchine è stato estrapolato uno studio sulla sua postura: Santa Rosa da pia fanciula popolo, in ginocchio e popolo, in ginocchio donn do fra cinta da una veste da francescana che mai e appartenne in vita; sul baldacchini del primi trasporti, poi, la postura divenne plastica, quasi teatrale. I disegni originali documentano l'evoluzione della Macchina tra il 1690 e il I80I (Museo Civico di Viterbo Inv. n.139/19/5), (elaborazione A. Salucci, D. Petrillo).
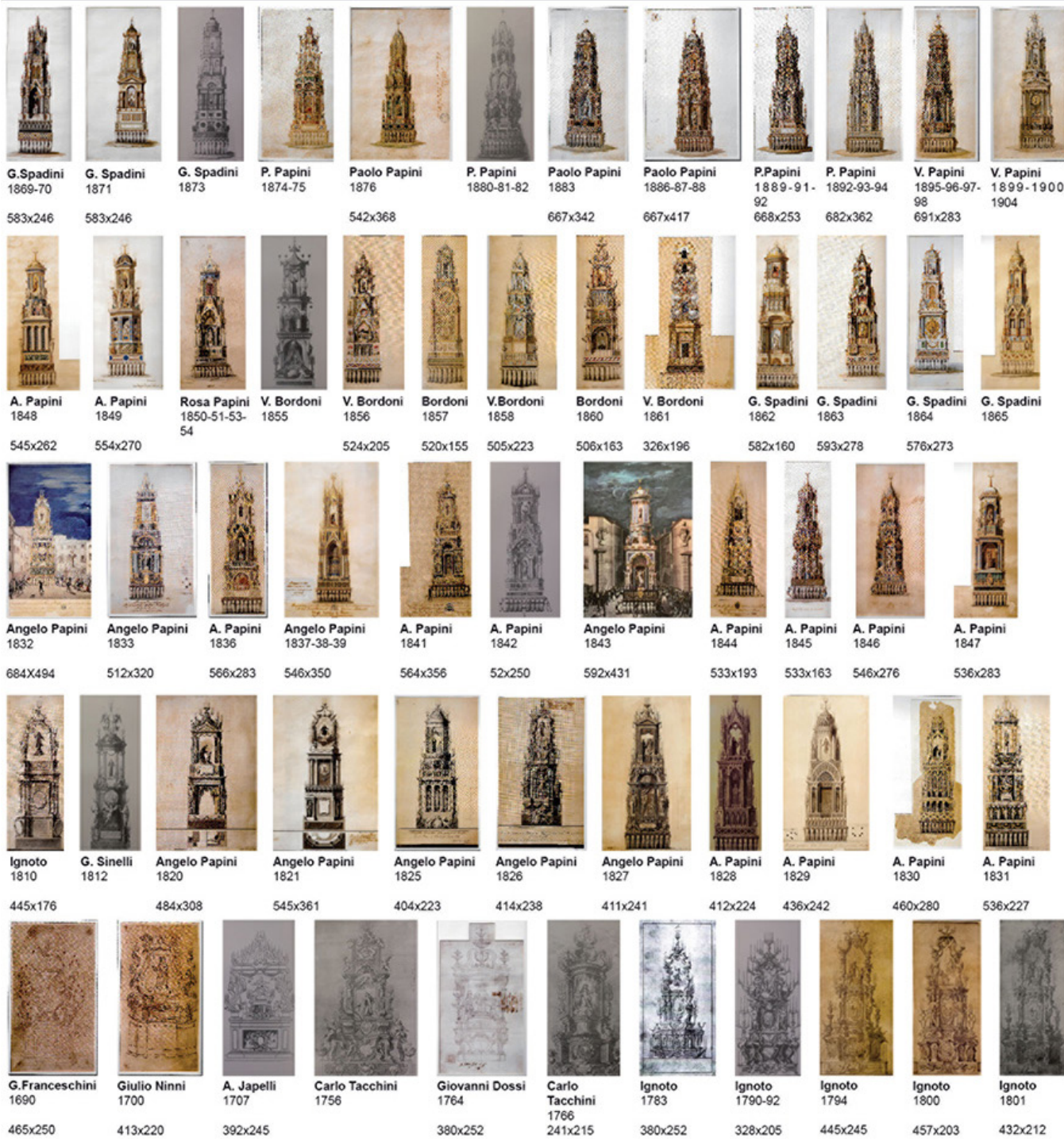
qualità della luce e dei sensori: metodologie di rilevamento che si connotano per economia di utilizzo, affidabilità, semplicità operativa, velocità di acquisizione e visualizzazione.

Un aspetto considerevole della fruizione di questo evento, è riferibile alla lettura sincronica e diacronica delle attività che si svolgono in Rete, nel tempo dell'evento-live, attraverso le piattaforme Social come Flickr e Instagram che amplificano la percezione, condivisione e la diffusione della performance urbana; l'esito di tali investigazioni comprende anche l'analisi delle immagini prodotte dalla diretta streaming che hanno fornito interessanti visuali da drone durante le fasi notturne della manifestazione (fig. 9).
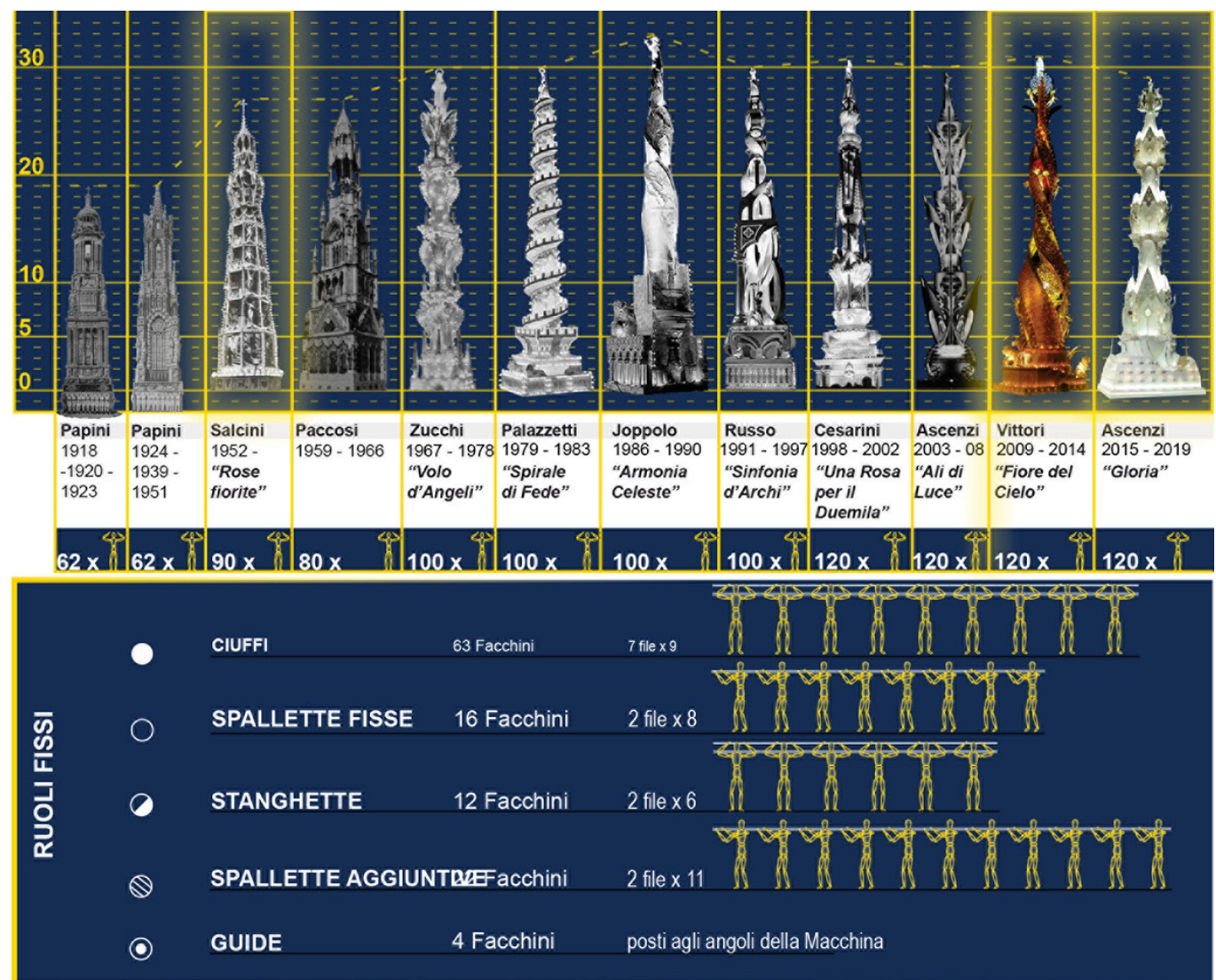

\begin{tabular}{|c|c|c|c|c|}
\hline \multirow{3}{*}{ 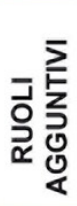 } & $\theta$ & LEVE & 20 Facchini & $\begin{array}{l}\text { spingono sulle } 4 \text { travi inserite nella parte posteriore della Macchina } \\
\text { per il tratto finale del percorso }\end{array}$ \\
\hline & \multirow[t]{2}{*}{ () } & CORDE & numero vari & $\begin{array}{l}\text { tirano } 2 \text { corde agganciate alla parte anteriore della Macchina per } \\
\text { il tratto finale del percorso }\end{array}$ \\
\hline & & CAVALLETTI & 8 Facchini & $\begin{array}{l}\text { addetti al posizionamento dei supporti posizionati sotto la base } \\
\text { della Macchina }\end{array}$ \\
\hline
\end{tabular}

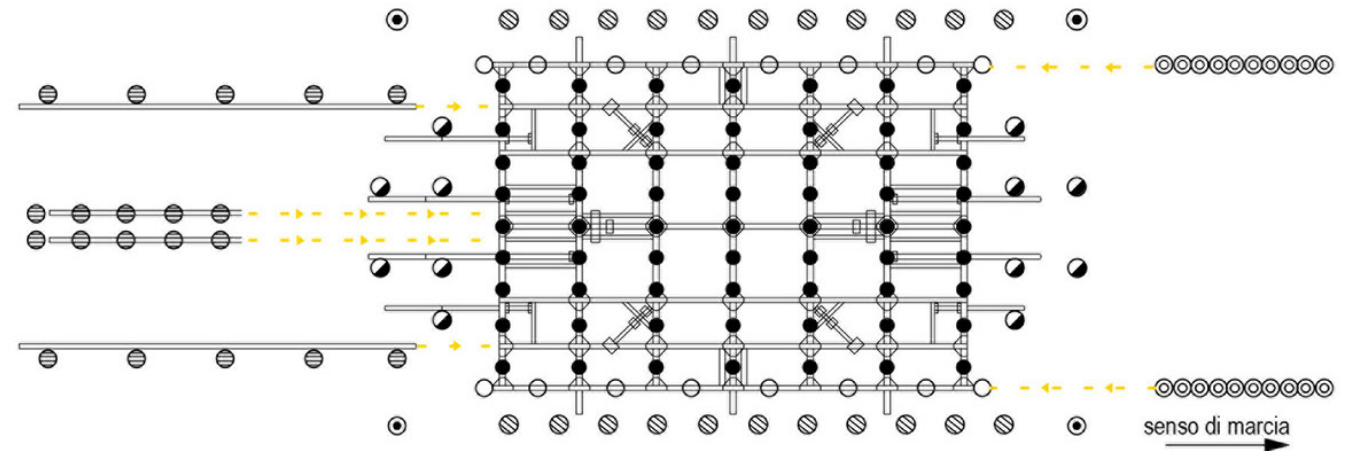


Interessante è anche l'esperimento di mobile-photography, messo in campo da qualche anno dal dipartimento DISUCOM dell'Università della Tuscia, che vede i suoi esiti in un progetto grafico che fa esplicito riferimento alla semantica di Instagram - piattaforma social utilizzata dagli autori stessi per la condivisione degli scatti - che segue due percorsi narrativi complementari che guardano, dall'interno, alle persone e alle cose, all'architettura, alla città, all'ambiente [Fiorentino 2017].

\section{Conclusioni. Restituire un'atmosfera, una visione}

La città storica di Viterbo, discretizzata e descritta in queste brevi note, è evocata da una rappresentazione che privilegia volutamente una raffigurazione planare, - proiezioni parallele secondo piani mongiani - continuamente riferita alla mole processionale ricostruita con l'ausilio dei disegni di progetto originali, conservati presso le istituzioni comunali, che come è noto, sulla base di un concorso pubblico vengono rinnovati ogni cinque anni [Salucci 20 I8]. Nelle elaborazioni a margine del presente contributo - parte sostanziale di questa fase del lavoro di ricerca - le facciate urbane che definiscono i limiti spaziali della performance urbana, sono potremmo dire, 'punteggiate' da figure - fruitori, cittadini, devoti, siano essi stanziali o in transito - che seguono dalle varie quote il passaggio del corteo di luce, suoni, masse. L'obiettivo è quello di restituire un'atmosfera, una visione. Le informazioni spaziali sono riferite, non soltanto alle qualità architettoniche di un riconosciuto patrimonio storico materiale di grande pregio - quello della città di Viterbo, in cui da secoli si celebrano rituali devozionali per il culto della Santa Patrona della città - ma sono altresì orientate alla narrazione del coinvolgimento emotivo suscitato dal complesso sistema di attività che questo evento processionale mette in campo.

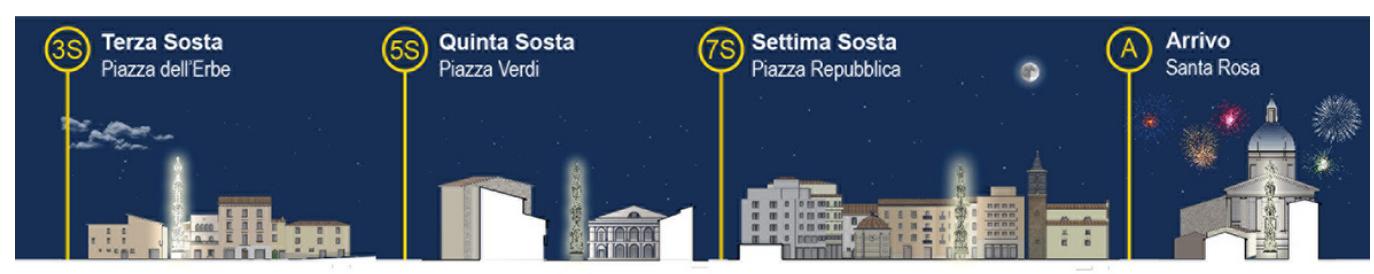

Fig. 9. Viterbo e lo spazio urbano dell'evento: rilevamento del coinvolgimento emotivo. Tluoghi coinvolti dal Trasporto rappresentat in proiezione parallela simulando levento dal vivo rilevato attraverso la partecipazione diretta. In basso: trailer dei fotogrammi principali dell'evento e dalla diretta live-streaming dell'evento; vista aerea della girata in Piazza del Plebiscito (fotografie di D. Petrillo, 3 settembre $20 \mid 8$, sera).
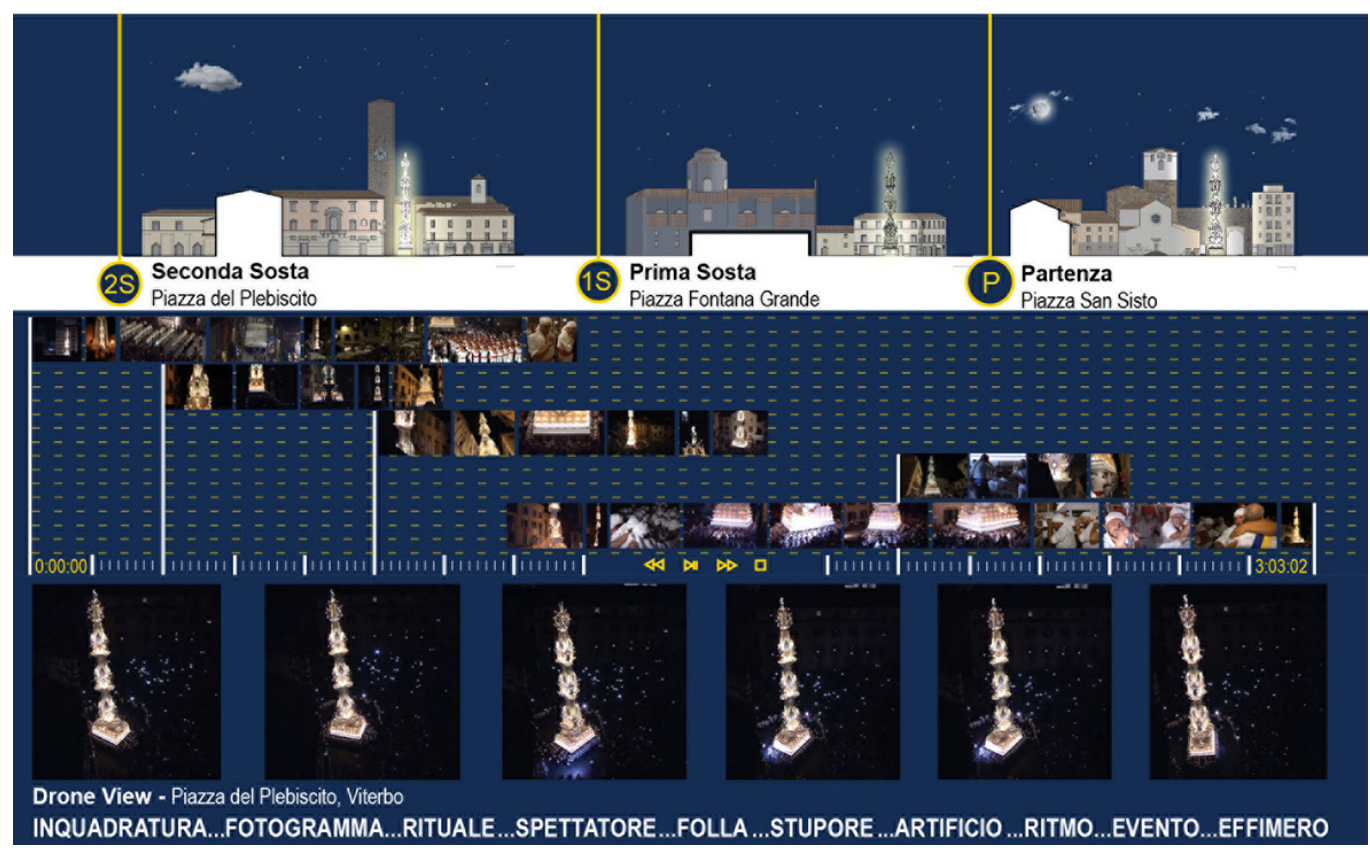
Fig. I0.Viterbo e lo spazio urbano dell'evento: rilevamento del

coinvolgimento emotivo.

II racconto dell'evento

Mosaico di immagini

Mosaico di immagini
rilevanti raccolte durante

rilevanti raccolte durante
il rito preparatorio del

Giro delle Sette Chiese.

Nel primo pomeriggio

del 3 Settembre i Facchin

giungono a piedi alla

prima tappa, il Duomo

di San Lorenzo, dove

una volta riuniti ricevono

i saluti delle autorità;

da qui ragsiuntono,

da qui rging

di Santa Gina, la Chiesa

di Santa Gacina, dove

ricevono una simbolica

foglia con una spina, che

li proteggerà durante

trasporto. Arrivati alla

chiesa di Santa Maria

Nuova, terza tappa,

depongono una corona

al Sacrario, recandosi

poi in Piazza del

Plebiscito nella Chiesa di

Sant'Angelo, quarta tappa;

da qui raggiungono il

Monumento al Facchino e

gli recano omaggio; quind

giungono alla Chiesa della

Trinità, quinta tappa e alla Basilica di San Francesco alla Rocca. Raggiungono

poi il bosco del Convento dei Cappuccini, dove

salutano tradizionalmente

familiari e amici, e salgono

al Tempio di Santa Rosa,

settima tappa, e a San

Sisto, ottava tappa, dove

ricevono la benedizione

In Articulo Mortis e dove

la Macchina di Santa

Rosa, li attende per la

processione della sera

processione della sera

settembre 2019 , giorno)
In questo processo di analisi condotto su un patrimonio intangibile Unesco, la Fotografia sia essa orientata alla documentazione o al rilevamento - investe tutti i campi dell'indagine conoscitiva e sostiene, alle varie scale - della misurazione o della documentazione, della condivisione - l'operare dell'architetto: osservatore privilegiato di una performance che si pone come mediazione tra spazio e identità di un luogo, espressione di una imprescindibile e necessaria 'connessione' tra terra e cielo [I].
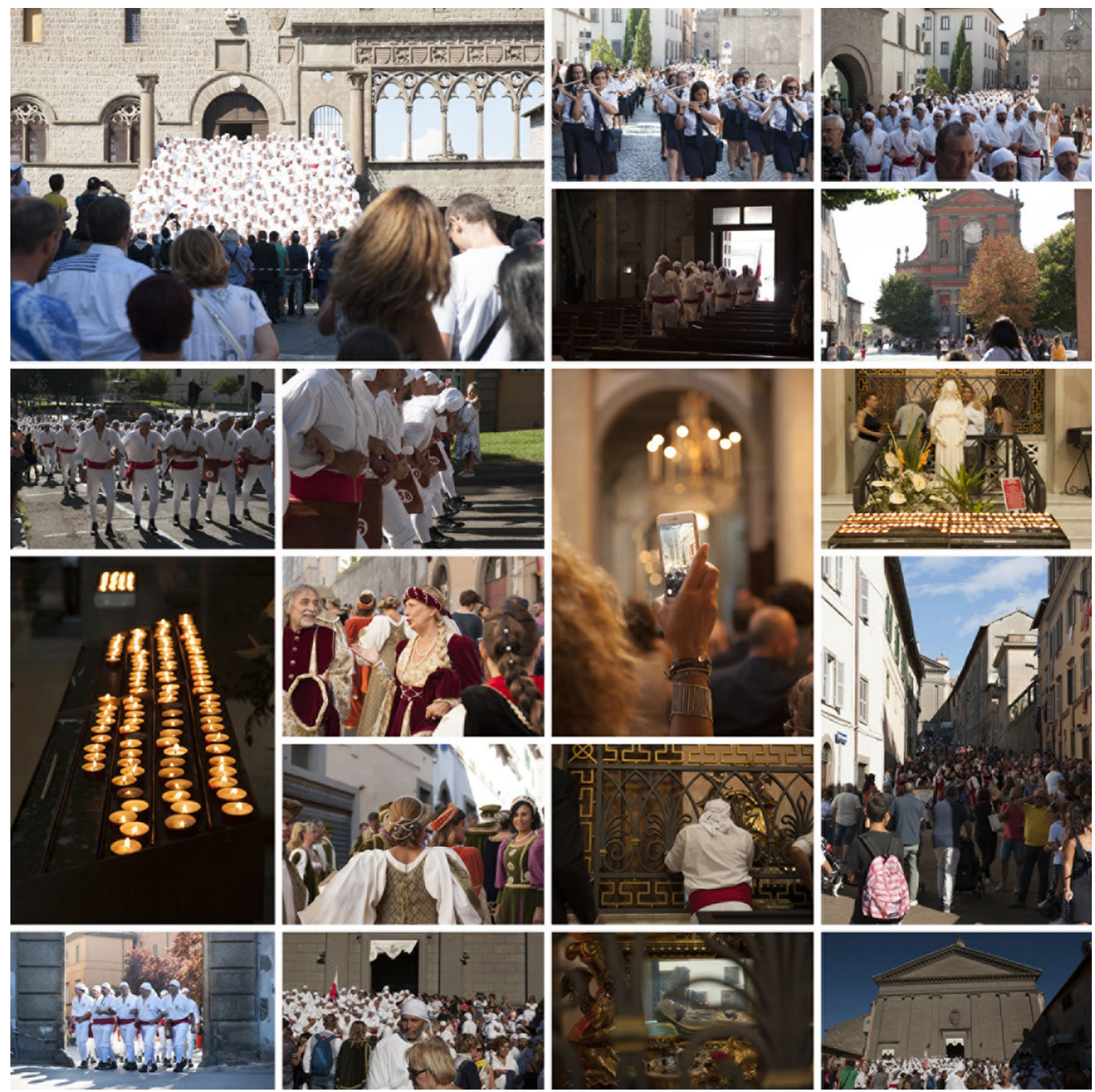

Note

[I] Questo paper è il risultato di una comune discussione ed elaborazione fra le autrici Antonella Salucci (Premessa, Paragrafo 3. Conclusioni) e Donatella Petrillo (Paragrafi I, 2). La documentazione fotografica originale e le elaborazioni sono a cura delle autrici.

Riferimenti bibliografici

Bentivoglio Enzo (20 I 6). II Giubileo del 1450 e il culto di Santa Rosa, L'arrivo del Rinascimento a Viterbo e la Chiesa di Santa Rosa. Roma: GBEditoriA.

Bentivoglio Enzo (20 I 7). I progetti del "Tempio di Santa Rosa" a Viterbo diArnaldo Foschini (1 908) e le tarde idee di completamento dai suoi inediti schizzi (1967). Roma: GB Editori.

Bentivoglio Enzo, Valtieri Simonetta (2012). Viterbo nel Rinascimento. Roma: GBEditoriA. 
Falcioni Giorgio (200 I). La Macchina di Santa Rosa. Memorie, feste, curiosità, folclore, culto, protagonisti.Viterbo: Agnesotti Editore.

Fiorentino Giovanni (20 I7).Viterbo, la fotografia e la vita quotidiana. I colori (e gli occhi) di Santa Rosa. In Santa Rosa, le persone le cose. Santa Rosa, le cose, le persone. II bianco e il rosso.Volume 2 DISUCOM. Università degli Studi della Tuscia, pp. 3-7.Viterbo Edizioni Sette Città.

Koolhass Rem (20I4). Fundamentals. Architettura non Architetti. Monditalia. La Biennale di Venezia, $14^{a}$ Mostra Internazionale di Architettura Venezia 20 /4. Catalogo della mostra. Venezia: Marsilio.

Nardi Patrizia (20|4). Patrimonio del Cuore, Patrimonio dell'Umanità UNESCO. Le Feste e la Rete. In I Beni Culturali. Tutela, valorizzazione, attività culturali, architettura contemporanea, bioarchitettura e turismo. Speciale Macchina di Santa Rosa da Viterbo Patrimonio UNESCO, numero 2, anno XXII, Maggio-agosto 2014, pp. 83-96. Viterbo: BetaGamma Editrice.

Parlato Enrico (2002). La processione di Santa Rosa a Viterbo: dall'iconografia quattrocentesca alle macchine barocche. In Fagiolo Marcello. Atlante Tematico del Barocco in Italia. II "Gran Teatro" del Barocco. Le capitali della festa. Roma: De Luca Editori d'Arte, pp. $251-260$.

Salucci Antonella (2016). The urban space of the ephemeral heritage. Celebrations of big shoulder-borne processional structures. In Gambardella Carmine (ed.). World Heritage and Degradation. Smart Design, Planning and Technologies. XIV International Forum "Le vie dei Mercanti", Naples and Capri, I6/I 8 June 2016, pp. 1207-12 I4. Napoli: La scuola di Pitagora Editrice.

Salucci Antonella (2018). Comunicazione e Valorizzazione del Patrimonio Immateriale Unesco. II Trasporto della Macchina di Santa Rosa da Viterbo, Italia. In Salerno Rossella (a cura di). Rappresentazione/Materiale/lmmateriale. Drawing as (in)tangible representation. $40^{\circ}$ Convegno Internazionale dei Docenti delle Discipline della Rappresentazione XV UID Congresso della Unione Italiana per il Disegno, Milano I 3- 15 settembre. Roma: Gangemi Editore, pp. I 402- I 4 I 2.

Trione Vincenzo (20।4). Effetto città. Arte cinema modernità. Roma: Bompiani.

Unali Maurizio (20 I0). Architettura Effimera. <http://www.treccani.it/enciclopedia/architettura-effimera_\%28XXI-Secolo\%29/>.

Unali Maurizio (20I5). Rappresentare l'immateriale. Cultural heritage e poetiche dell'effimero / Representing the intangible Cultural Heritage and the Poetics of the Ephemeral. In Giovannini Massimo, Arena Marinella, Raffa Paola (a cura di). Spazi e Culture del Mediterraneo. Ricerca Prin 2009-20 I I. Napoli: La scuola di Pitagora, Pp. I027-I 04 I.

UNESCO Rete delle Grandi Macchine a Spalla Italiane: <https://ich.unesco.org/en/RL/celebrations-of-big-shoulder-borneprocessional-structures-0072I>.

Valtieri Simonetta (2017). Viterbo e i Giubilei del Rinascimento (I 450-1550). Storia, personaggi, opere. Roma: GBEditoriA.

\section{Autori}

Antonella Salucci, Università degli Studi “Gabriele d'Annunzio" di Chieti-Pescara, antonella.salucci@unich.it Donatella Petrillo, Università degli Studi "Gabriele d'Annunzio" di Chieti-Pescara, donatellapetrillo@gmail.com

Per citare questo capitolo: Salucci Antonella, Petrillo Donatella (2020). Connessioni tra terra e cielo. Forma e immagine nel racconto delle qualità intangibili di uno spazio urbano/Connections between earth and sky. Shape and image in the representation of the intangible qualities of an urban space. In Arena A., Arena M., Brandolino R.G., Colistra D., Ginex G., Mediati D., Nucifora S., Raffa P. (a cura di). Connettere. Un disegno per annodare e tessere. Atti del $42^{\circ}$ Convegno Internazionale dei Docenti delle Discipline della Rappresentazione/Connecting. Drawing for weaving relationships. Proceedings of the 42th International Conference of Representation Disciplines Teachers. Milano: FrancoAngeli, pp. 3774-3799. 


\title{
Connections between Earth and Sky. Shape and Image in the Representation of the Intangible Qualities of an Urban Space
}

\author{
Antonella Salucci \\ Donatella Petrillo
}

\section{Abstract}

The article presents the results of a research about the representation of intangible cultural heritage, with specific reference at the Old Town of Viterbo (Lazio, Italy) that, in the traditional event of the festivities for the celebration of the city's Saint patron, stages a complex system of relations, both spatial and emotional, that are interesting to document as one of the most famous cultural expressions of Italian tradition.

In accordance with the objectives of this survey, we propose the narration of the "Connections between earth and sky" that are established between the city and its inhabitants, by the event of the transport of a shoulder-borne processional structure, which achieved the UNESCO recognition since 20 I3: an ephemeral event where sounds, lights, crowd and emotional involvement create a fascinating interaction system. The extensive work of historians about this theme allows us to build a preliminary picture, functional to the critical observation and to the narration of the object of the research. In this direction we accomplished this goal through two elaborative spheres, supported by the Drawing and Photography languages: description of the modification of urban spatiality and emotional involvement; sampling, classification and cataloguing of graphic, iconographic and textual documents; process of surveying the urban sceneries; critical and elaborative analysis of data. Some of the images that run parallel with the text testify to the process of research.

Keywords

Intangible Cultural Heritage, photography, drawing; UNESCO shoulder-borne processional structures; Viterbo, Italy.

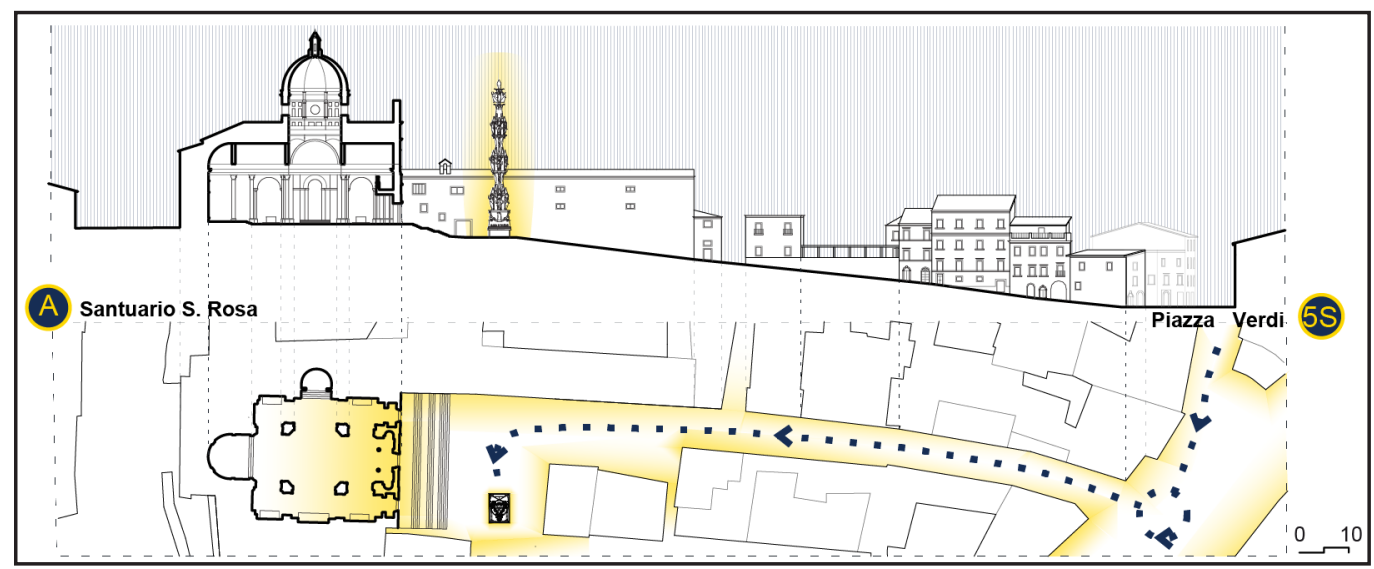




\section{Premise. Connection between earth and sky. Towards a survey method about intangible qualities of an urban space}

The article proposes to show the progress of a long process of study, involving several researchers in the area of Drawing, concerning both the process of survey, and the languages of Drawing and Photography, for the representation of architectural and intangible cultural heritages.

It suggests some interpretations for the intangible qualities of an urban historical scenery during the traditional Celebration of Santa Rosa da Viterbo (Lazio, Italy), which involves, since several centuries, a whole community in a complex system of devotional rituals.

It describes some qualities of a city, with its streets and historical squares. Spaces characterized as border areas of an urban set. A sort of scenic backgrounds that, during the celebration, transform revealing their porosity and sensitivity qualities to the passage of a surprising ephemeral apparatus in procession: mutable, changeable, magnificent.

In terms of methods the integration of languages of representation, Drawing and Photography, facilitate the interpretation of the interactions between the urban spaces and an intangible cultural heritage of Italian tradition. The language of Drawing, through the architectural survey of some parts of the old town, describes the metamorphosis of the city spaces crossed by the celebrations; the survey of emotional involvement was entrusted to the language of Photography, through the photographic documentation of the live event edited by the authors.

We wanted to analyse and represent the shared space, which is the place where the connection goes on stage: the space between people, between things, between places.

On one side there is the crowd, the audience, the city and its squares; on the other side there is the night sky, which is, at the same time, scenic background and protagonist of the event. The meeting place is represented by the processional apparatus, the Tower crossing the streets, metaphorical element of connection between earth and sky.

The work of analysis, reading and communication -ased on the extensive work of the historians on the theme- is structured in three parts.

The first one summarizes the Italian placement in the system of Intangible UNESCO Heritages: the Transport of the Macchina di Santa Rosa is included in the "Big Shoulder-borne Structures Network", that is part of the Representative List of Intangible UNESCO Heritages since 2013.

The second part is about the reading of urban spaces interested by rituals connected to the urban performance of processional transport:

- surveying urban sceneries that run along the processional path of the Tower;

- analysis of the "Giro delle Sette Chiese" procession (Seven Churches Tour), performed by 'porters' in the hours that precede the passage of the Tower of Santa Rosa;

- surveying the Temple of the Saint, designed in its current state by one of the masters of Roman School, Arnaldo Foschini;

- surveying the original projects drawings of the old Towers, kept in the Civic Museum of Viterbo, that made possible the codification of the porters hierarchy which are the protagonists of the event, together with the crowd.

The third part is about the description of the emotional involvement that we have experienced directly, looking for effective means of narration.

\section{The UNESCO Network of Italian Big Shoulder-borne Structures}

The project of the Big Shoulder-borne Structures Network, that achieved the UNESCO recognition in 2013, was launched in 2005 by five Italian communities, Viterbo, Nola, Palmi, Sassari e Gubbio; the latter with its Ceri [Belardi 201 I] later presented its own nomination individually. The communities have in common the collective ritual of a celebrative procession with the transport of big shoulder-borne structures as manifesto of the identity of their places of belonging [Nardi 2014, pp. 83-96] (fig. I). 
Fig. I. Representative List of Italian Intangible Cultural Heritage - ICH.The Italian "Intangible Cultura Heritage" represented by the categories of the UNESCO candidacy dossier In highlights the cities belonging to the "Big Shounging to the Prochsilder-Borne Network": the Festa dei Giglidi Nola (Napoli), Gigli di Nola (Napoli) dili Candareri di Sassari. Sardegna; the Varia di Palmi (Reggio Calabria), Calabria; the Macchina di Santa Rosa a Viterbo: <Lazio http://www. unesco.it/it/Documenti/ Detail//80> (elaboration by A. Salucci, D. Petrillo).
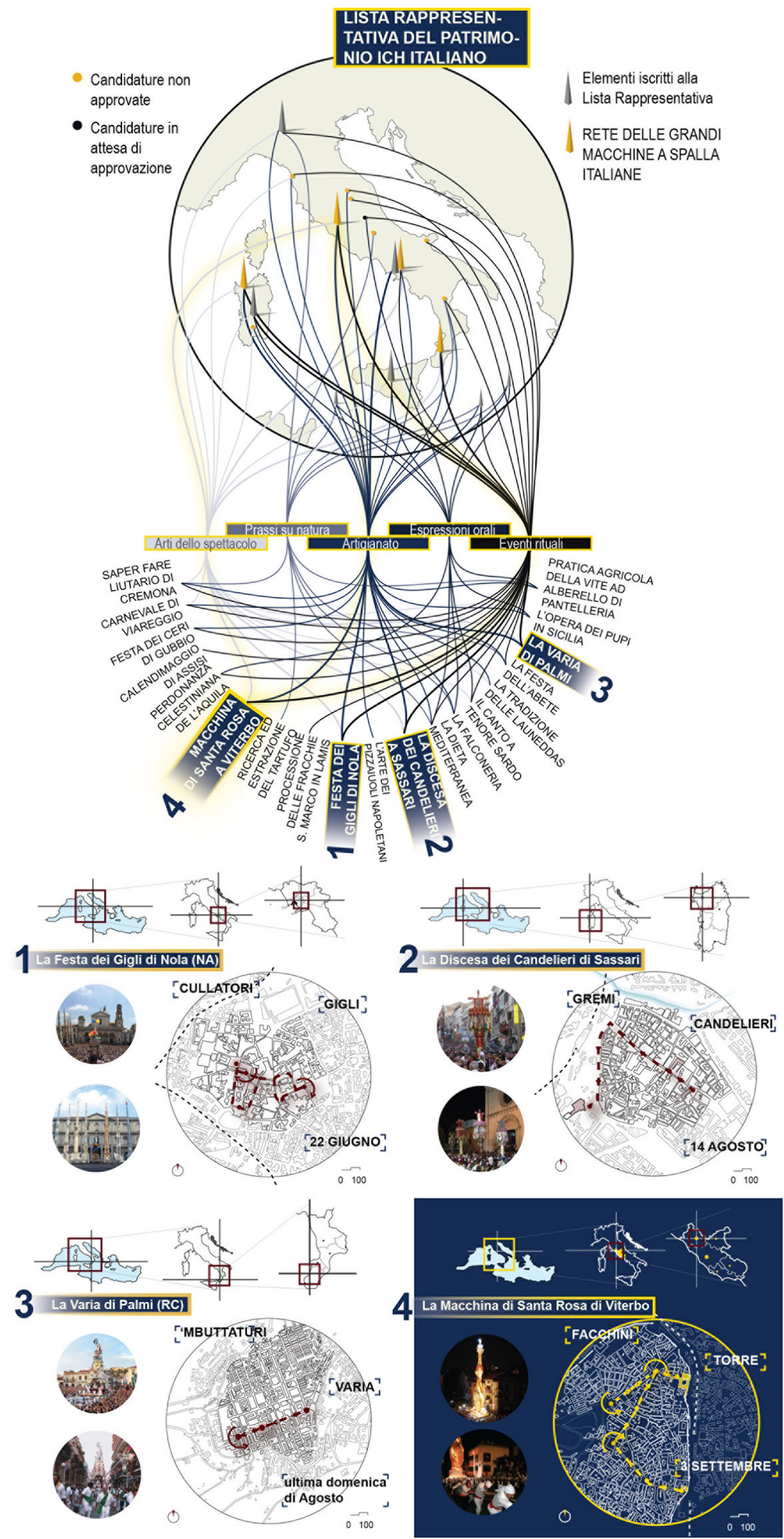
The Celebration of the Gigli di Nola (Campania, 22nd June), consists in the diurnal transport of the Ceri, 8 wooden towers, 25 meters tall, for a weight of 25 quintals, carried by 120 men, called 'cullatori'.

The Discesa dei Candelieri di Sassari (Sardinia, I 4th August), consists in the transport of Candelieri, huge wooden candles with a weight of about 4 quintals, cylindrical in shape, carried on the shoulders of 8 porters each, which are gathered in associations called 'Gremi'.

The Celebration of the Varia di Palmi (Calabria, August) consists in the transport of a big scenic cart shaped like a cloud, 16 meters tall and for a weight of 200 quintals; the porters, gathered in corporations, are called 'mbuttaturi'.

The Celebration of Santa Rosa from Viterbo (Lazio, 3rd September) consists in the nocturnal transport of a big illuminated structure, 28 meters tall weighting 50 quintals, carried on

Fig. 2. Survey and analysis of the places of the event.Viterbo, Old Town. Crossings abacus. Survey of the urban spaces, Stops and Crossings interested by the transportation of the Tower of Santa Rosa (elaboration by A. Salucci D. Petrillo).

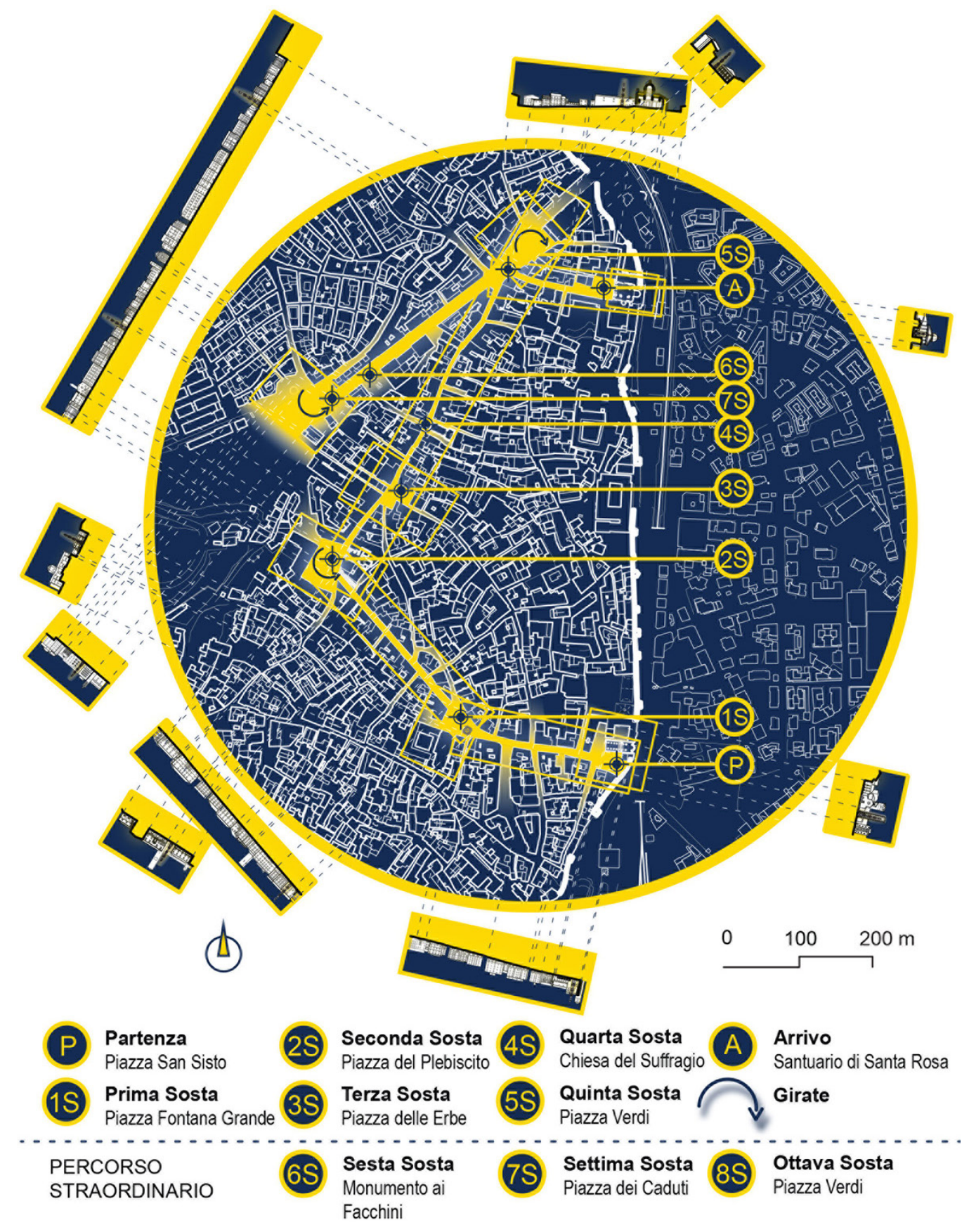


the shoulders of about 120 porters, called 'facchini'. The path is about 1,2 km long and is carried out in about 3 hours [Falcioni $200 \mathrm{l}$ ]. For the project, every five years a public contest is held [Parlato 2002] [Salucci 20 I 6; 20 I 8].

\section{The urban space of the event}

Placed along Via Francigena, Viterbo became an important European political centre when Pope Alexander IV (|254-|26|) decided to move to the city the papal Curia for the first Conclave in history; along with it, all of the most important families, belonging to the Roman nobility, moved in Viterbo, the Farnese among them. The path of the Transport, which was transformed significantly, is tied to the urban development and to the political history of the city.
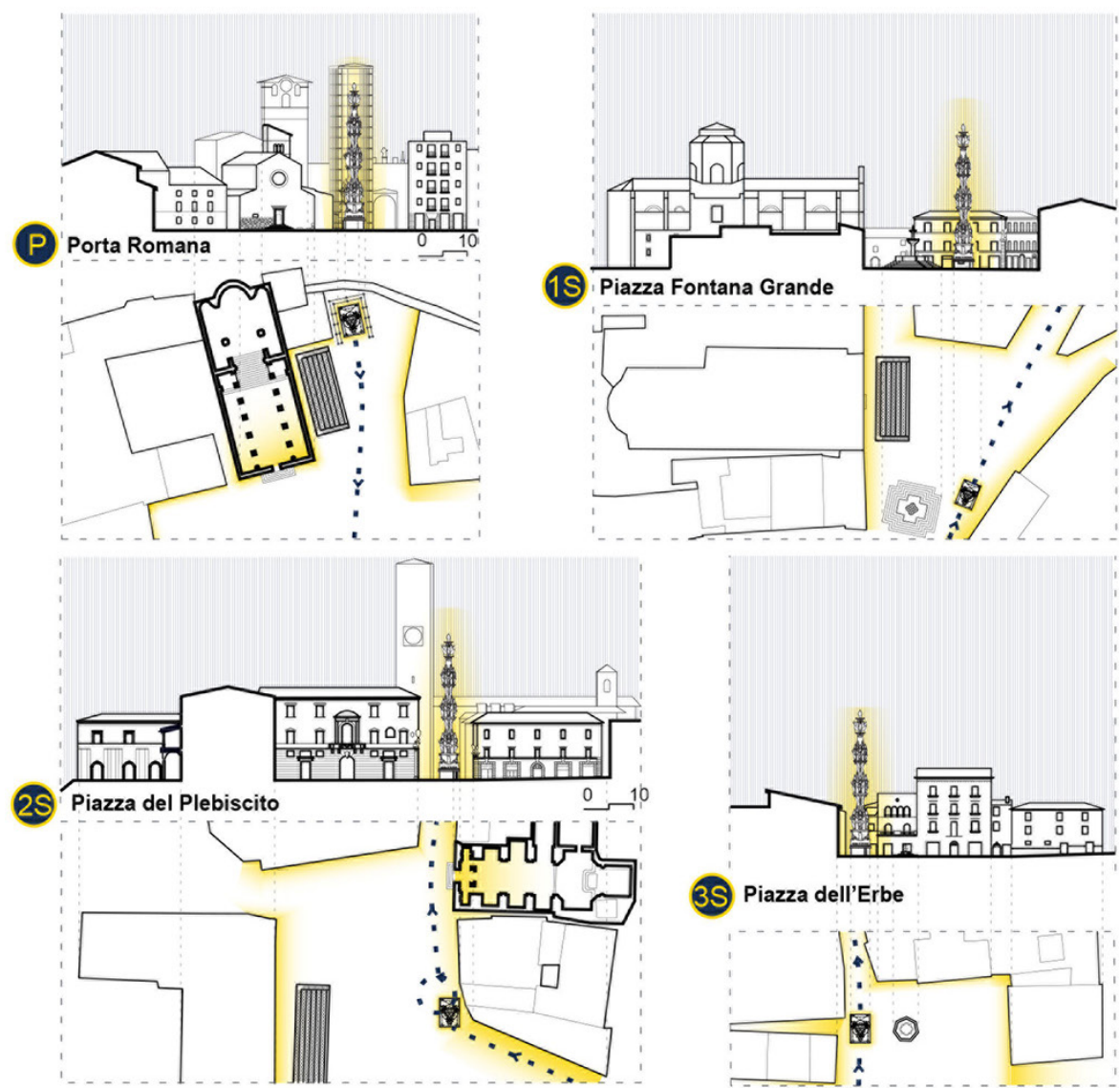

35

Piazza dell'Erbe

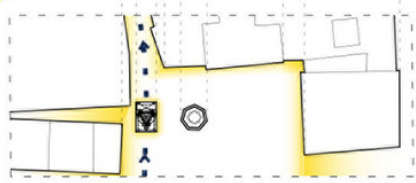

Fig. 3 Survey and analysis of the places of the event. Viterbo, Old Town The Stops. Survey of the processional Stops (see fig. 2). The city's historical Squares become the sceneries of the most strongly felt moments of the Transportation. The stops are seven - eight in case of extraordinary transportations - which are: Piazza San Sisto; Piazza Fontana Grande: Piazza del Plebiscito: Piazza dell'Erbe; Chiesa d Santa Maria del Suffragio; Piazza Verdi; Santuario di Santa Rosa (elaboration by A.Salucci, D. Petrillo).

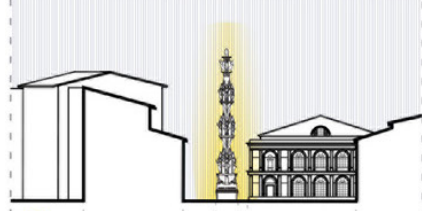

$5 S$ Piazza Verdi
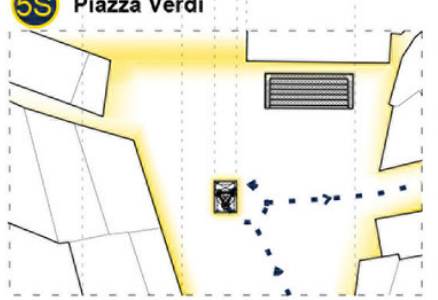

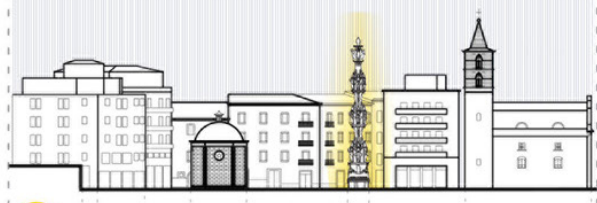

75 Piazza dei Caduti
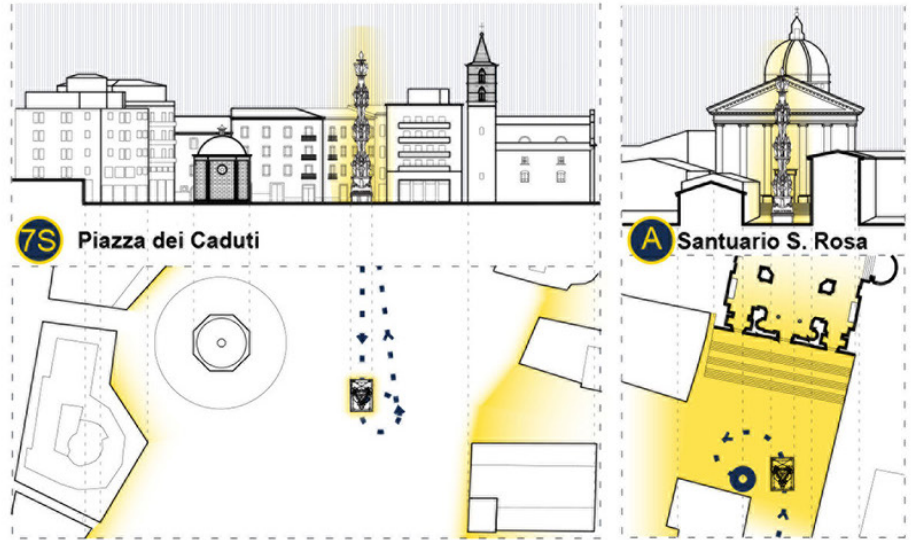
Fig. 4 Survey and analysis Vithe places of the event. Viterbo, Old Town. The Crossings. Survey of the processional crossings (see fig. 02), or the urban sceneries interested by the transportation. Th acades of the buildings overlooking the track of the Tower are flooded by the light emanating from it Via Giuseppe Garibaldi (da Piazza San Sisto a Piazza Fontana Grande) Via Cavour Giazza Fona Cavour (da Piazza del Plebiscito); a Plazza del Plebiscito); Corso Italia (da Piazza Verdi); Via Santa Rosa (da Piazza Verdi al Sagrato de Santuario di Santa Rosa), (elaboration by A. Salucci, D. Petrillo)
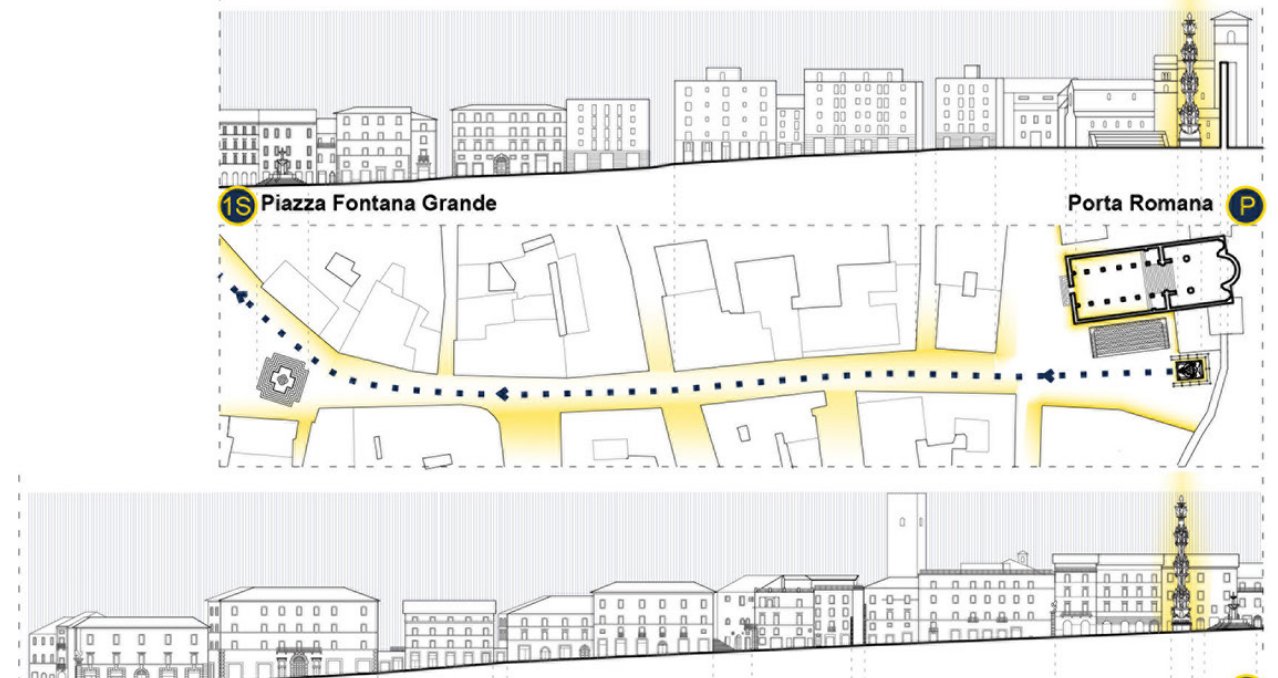
2S Piazza del Plebiscito

Piazza Fontana Grande 1S

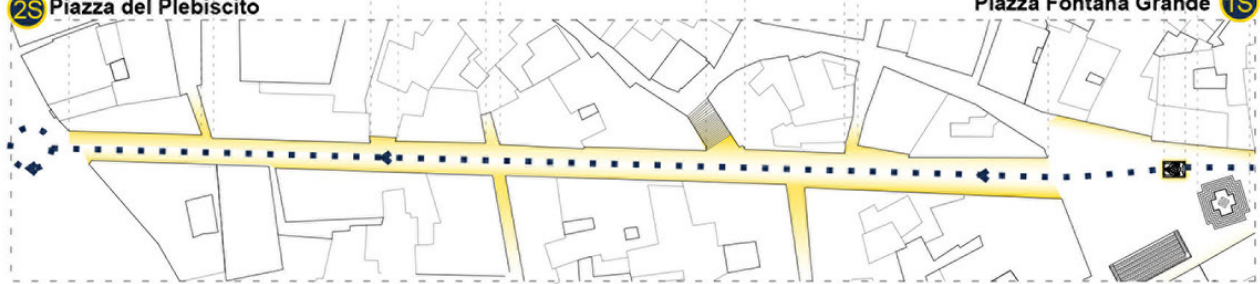

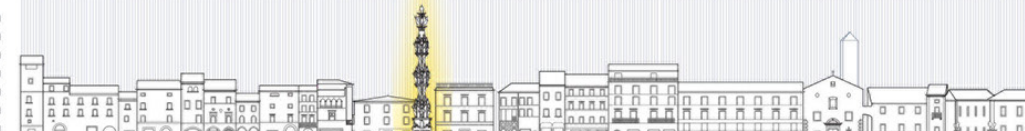
4S Chiesa del Suffragio 3S Piazza dell'Erbe Piazza del Plebiscito 2S
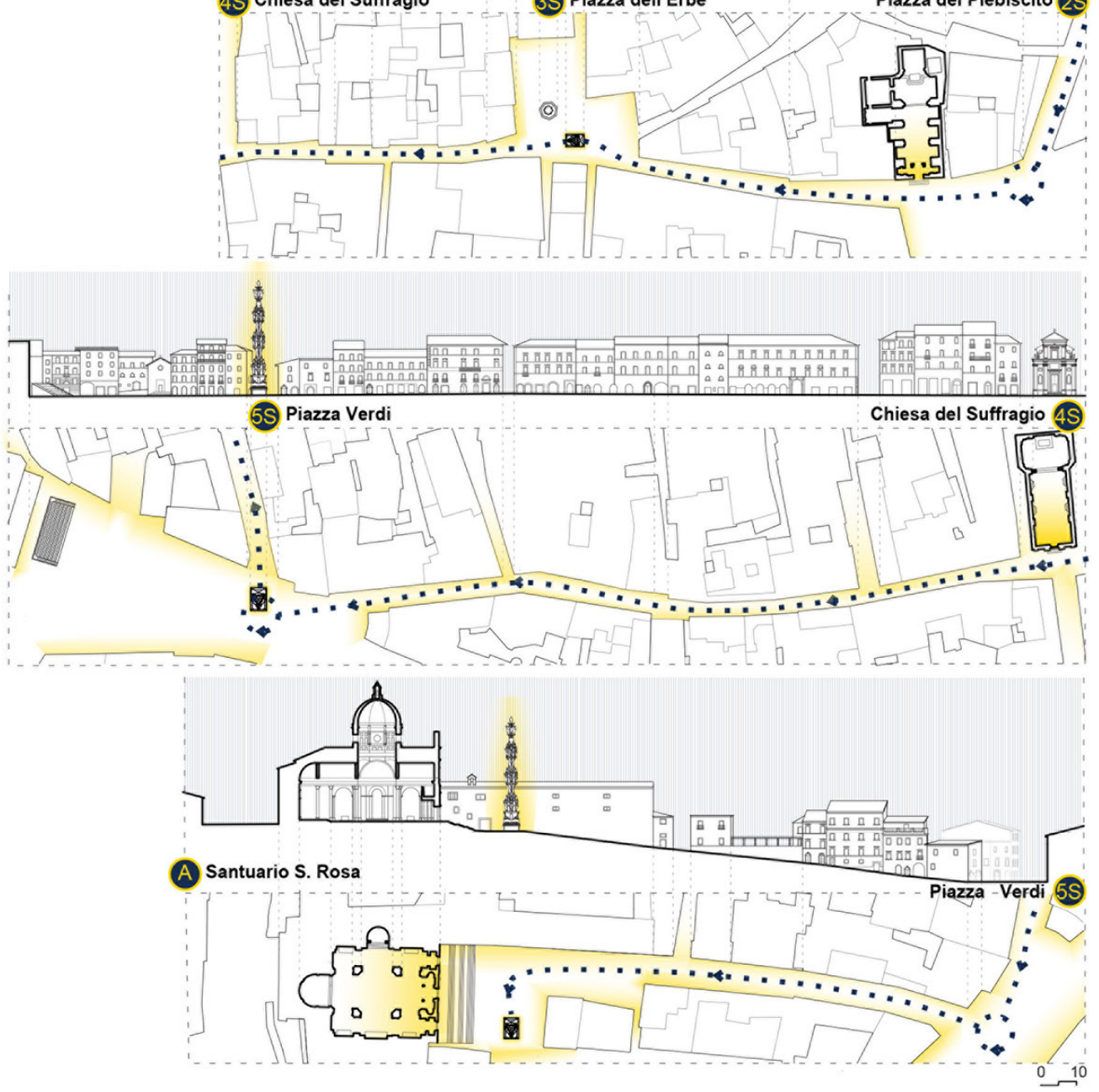
In order to narrate the complexity of the event -aying attention at the interference between the Tower and the urban spaces crossed by the procession- we finalized the procedures of survey to two principle observation categories: on one hand we represented the Stops, on the other the Crossings of the path, prioritising the representation in parallel projection by Monge's planes with the aim to describe accurately the urban sceneries interested by the passage of the 'illuminated structure' (fig 2).

The Stops of the urban path of the Tower of Santa Rosa (fig. 3) are seven, eight in case of extraordinary transports; moreover, in certain occasions the tower performs a full turn on itself, the 'girata', to allow the crowd to admire it from all angles [Salucci 20 16; Salucci 20 I8] The transversal sections of these urban spaces describe the Stop of the Tower during its transport and highlight some of the most important moments of the event.

The illuminated structure stops in the historical squares of the city: on one hand stopping allows the porters to have a break, on the other hand it allows people, tourists and worshippers -gathered in a magmatic waiting crowd- to appreciate, during the break, the big visual impact of the structure and to nourish the empathy, the religious fervour, the collective emotivity.

From the month that precedes the transport, the city gets ready for the event attending, in San Sisto square, to the installation of a scaffolding, inside which the Tower is assembled: its image is hidden from bystanders until the day of the transport (fig. 3).

The Crossings (fig. 4) are described by longitudinal sections taken on the urban axis interested by the path of the Tower. The survey of the urban sceneries, lit by the light emanating from the passing structure, highlights an important symbology, tied to the assertion of power of the Farnese family.

The ritual of the transport is preceded by several preparatory events: one of the most important is the so called Giro delle Sette Chiese, (fig. 5) that the porters, I 20 'facchini', perform while being in formation, followed by the crowd of worshippers, in order to prepare emotionally for the event, visiting some of the most important religious places of the city in the

Fig. 5. Viterbo, Old Town. Giro delle Sette Chiese. Planimetric scheme.The Porters' ritual of spiritual preparation is an event within the event, long awaited by citizens, an it includes, a few hours before the Transportation, the Porters reunited in front of the Duomo di San Lorenzo, so that they can visiting they can visit, lined-up some symbolic places in Viterbo: Duomo di San Lorenzo, Chiesa d Santa Giacinta, Santa Maria Nuova, Chiesa di Sant'Angelo, Chiesa della Trinità, Basilica di San Francesco alla Rocca, Tempio di Santa Rosa, San Sisto (elaboration by A. Salucci, D. Petrillo).

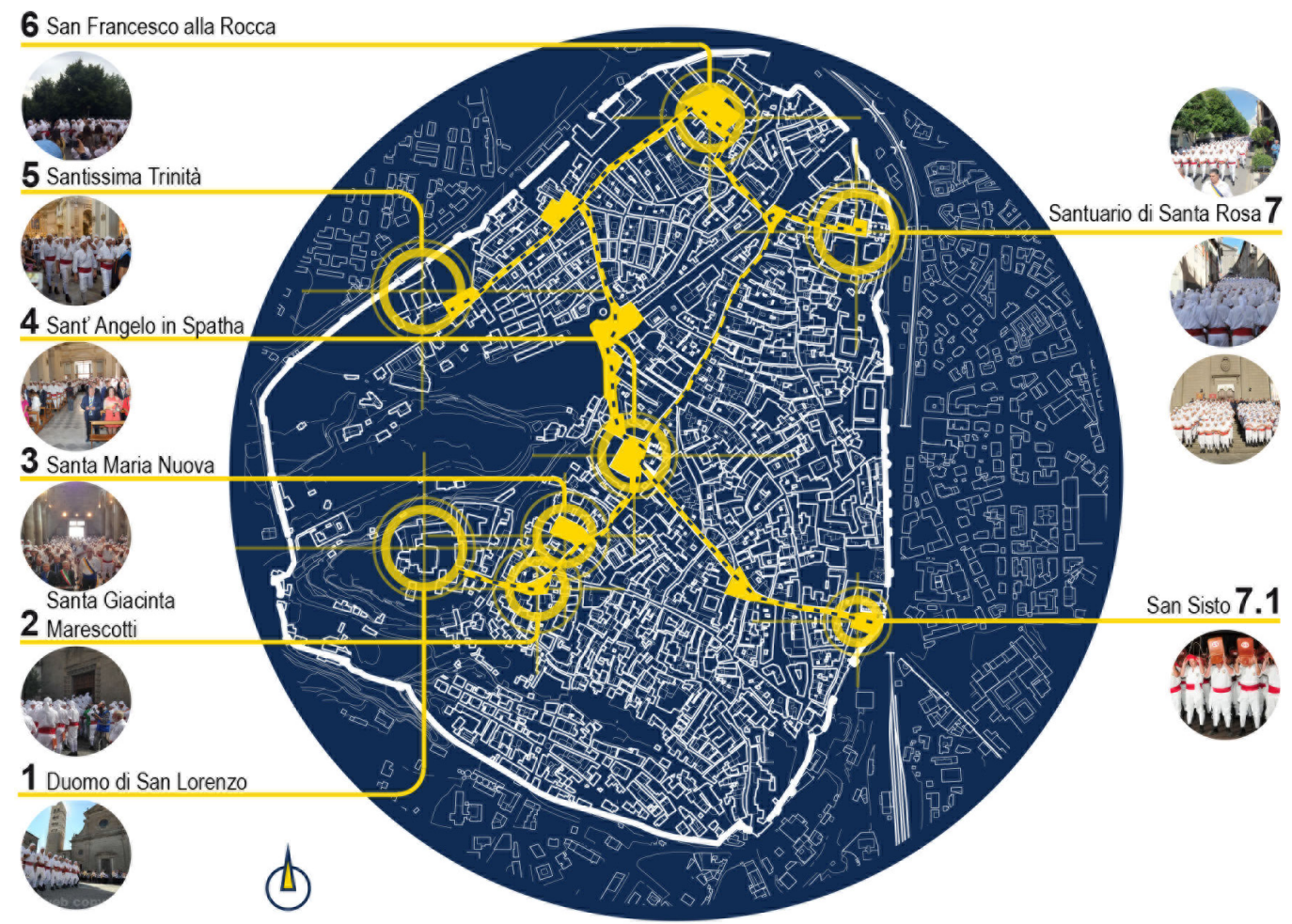


early afternoon of 3rd September: Dome of San Lorenzo, Church of Santa Giacinta, Church of Santa Maria Nuova, Church of Sant'Angelo, Church of Trinità, Basilica di San Francesco alla Rocca; Convent of Capuchin order; Temple of Santa Rosa, Church of San Sisto (fig. I0). This is an ancient ritual, of great effect, full of 'rituals within the ritual', gestures, symbols and traditions dating back to the very first transports.

The current Temple of Santa Rosa was built on a previous building dating back to 1632 and is annexed to the Poor Clares nuns' Convent [Bentivoglio 20 I 6; Valtieri 20 I7]. The engineer Vincenzo Federici, in 1844, worked on the facade. In 1908 a Competition was held, won by a young Arnaldo Foschini ( 884 - 1968), architect of Roman School. The project was realised starting with the reinforced concrete dome, that later remained the only part of the project completed [Bentivoglio 20 17]. On the subject of this research, we surveyed the building integrating direct, indirect and instrumental methods- allowing us to elaborate an horizontal section as well as two vertical ones, longitudinal and transversal (fig. 6).

An important collection of original project drawings of the Tower of Santa Rosa is preserved in the Civic Museum of Viterbo, with inventory number 139/19/5. The first drawing of the collection dates back to 1690. On these precious supports of paper, we can observe the evolving of the Tower through the years, until the first years of the past century, from Baroque baldachin to Gothic spire, assuming increasingly higher heights and increasingly modern styles (Parlato 2002: Salucci 20 I8] (figs. 7, 8).

The spectacle of the Celebration of the Tower of Viterbo is granted by the collaboration and sharing of knowledge adopted by several figures: besides the designers of the structure, a key role for the success of the event is played by the constructor, the craftsmen and the 'facchini', which are gathered in an association since 1978. The selection of new 'facchini' trough the prova di portata (strength trial) is part of the events that precede the transport: one of the most awaited (fig. 8).

Fig. 6. Viterbo, Old Town. The Tempio di Santa Rosa. Survey of the last Stop, the Church dedicated to the Saint and its parvis, the heart of its parvis, the heart of the Transportation: it ends here, where the Porters fove the Tower for the following days, so that devotees arriving in Viterbo for the celebrations can admire it. The origina project by architect Arnaldo Foschini showed an octagonal dome, inspired by Santa Maria del Fiore by Brunelleschi, leaning on a large tambour on pentives (elaboration by A.Salucci, D. Petrillo).
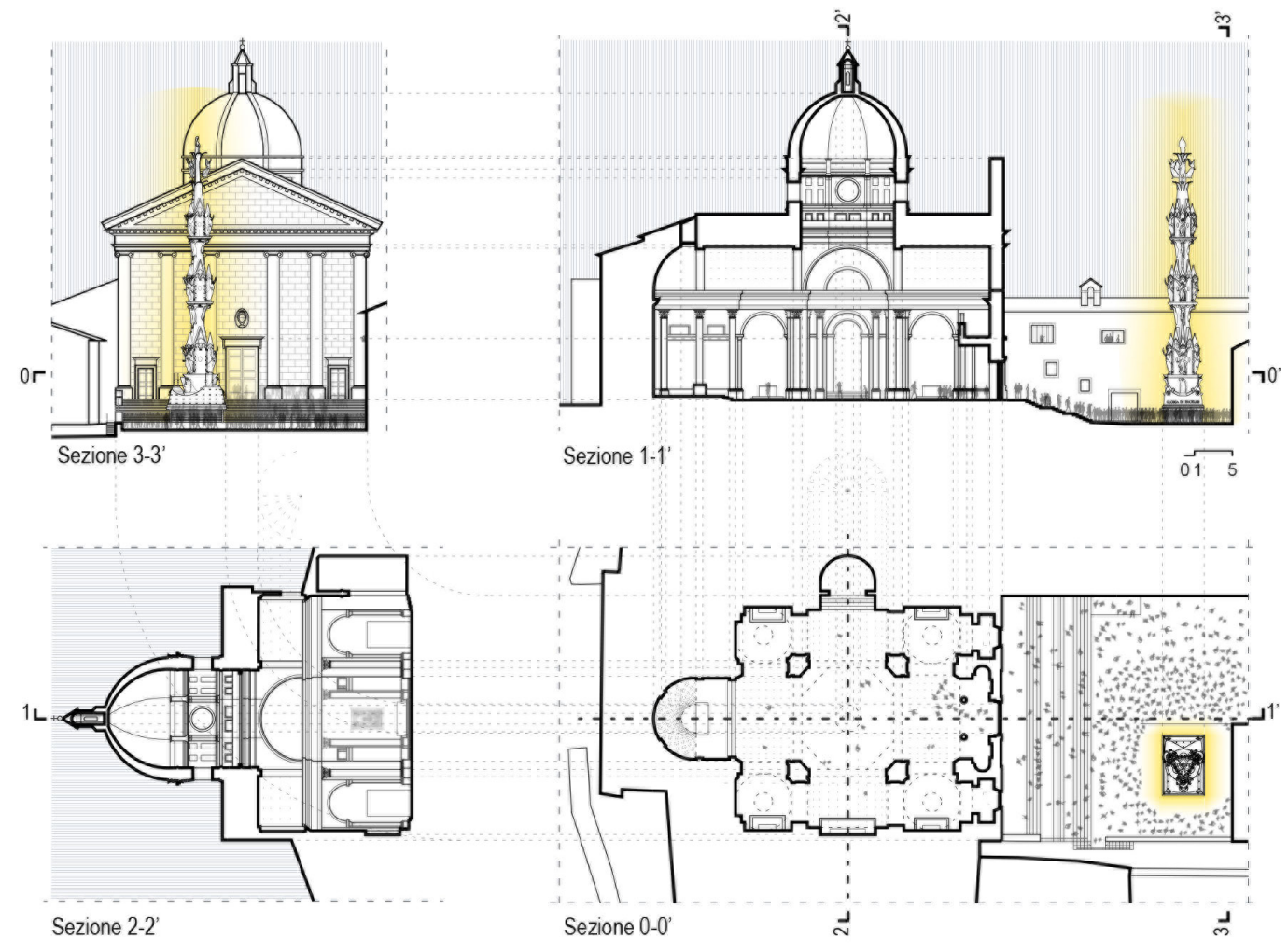

Sezione 2-2'

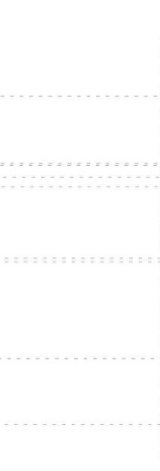

Sezione 1-1

$\widetilde{015}$ 


\section{The city as spectacle and survey of emotional involvement.}

We tried, with this brief article, to give a summary interpretation of a complex ritual of our tradition, that requires a multidisciplinary approach and most of all a direct participation. A reference point was the section Monditalia of Venice Biennale in 2014, curated by Rem Koolhass, who proposed an expositive path composed by multidisciplinary hybridizations intended as representation of a plural culture, in which the material and immaterial are mutable characters, always present in the work. [Koolhass 2014].

In the kaleidoscopic sequence of images, lights, sounds and colours of the Patronal Celebration of Viterbo, the bystanders participate to the event letting themselves be dragged in the visual and emotional delirium that stands before them, undergoing the charm of an event that, after centuries of rituals and traditions methodically repeated, is still able to raise wonder and astonishment [Trione 20 I4; Salucci 20 I8] (fig. 9).

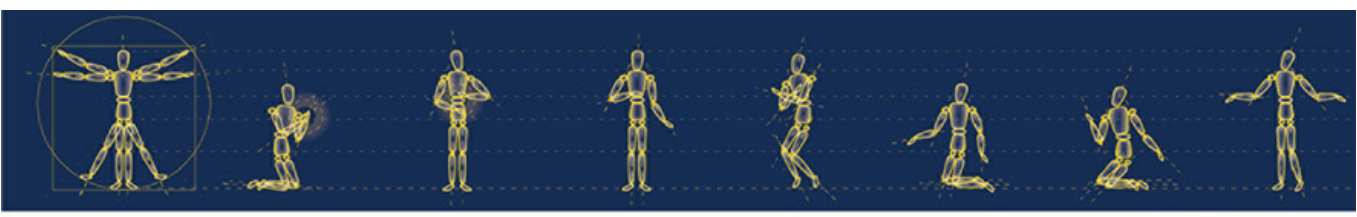

Fig. 7. Viterbo, the cult of the Saint and design drawings of the Tower. Study abacus. By the hagiography of Santa Rosa's life and by her representations on the models of the Tower, it was possible to extrapolate a study of her posture that shows changes related to the historical and politica historic ale political events of the city. from a pious, commoner. maiden, kneeling with hands clasped, to a woman adorned by the Franciscan habit that she never possessed in real life; on the first Towers, then, the posture became statuesque, almost theatrical.The original design drawings show the evolution of the Tower between 1690 and | $80 \mid$ (Civic Museum of Viterbo (nv $139 / 1915$ ) (elaboration by ASI5) D. Petrillo).
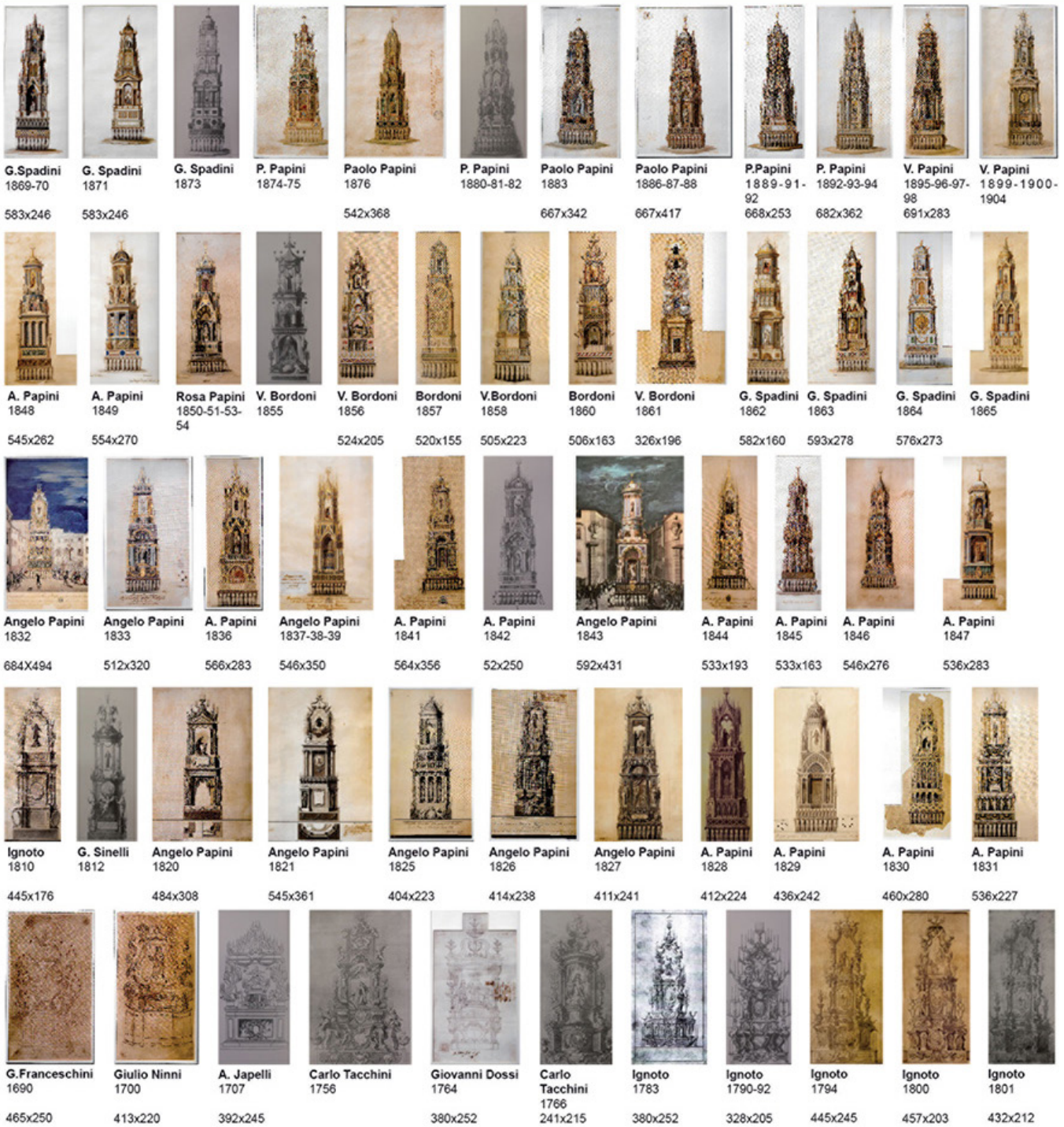
An installation that advances beyond the masses, configuring as an interface and as element of mediation, of sharing, between the city and its people.

The urban sceneries that compose the scene of the processional event, were reproduced based on a project of survey obtained by the integration of direct and indirect survey methods, utilizing acquisition and visualisation technology that allow 'structure from motion' procedures - reflex camera, smartphone and drone. Such procedures, as is well known, generate with a certain accuracy point clouds from digital images produced by 'mobile-andlow-cost' cameras, relying on the quality of the light and of the sensors for the writing of the information: survey methods characterized by their economic use, reliability, operational simplicity, acquisition and visualisation speed.
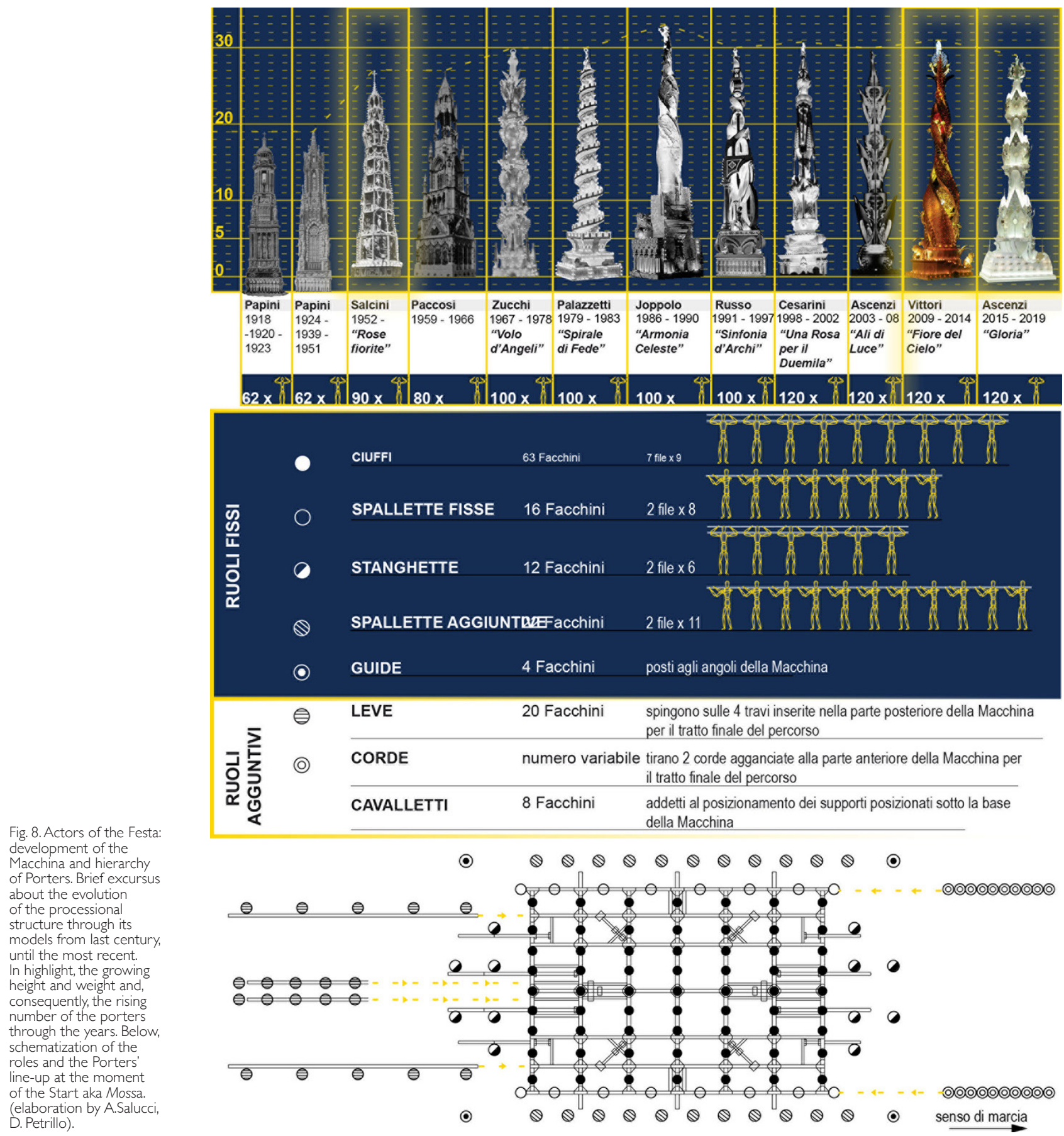

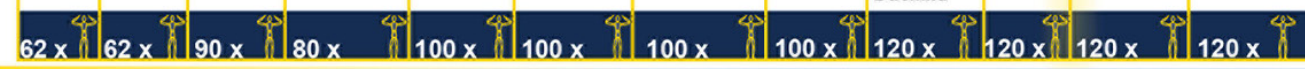

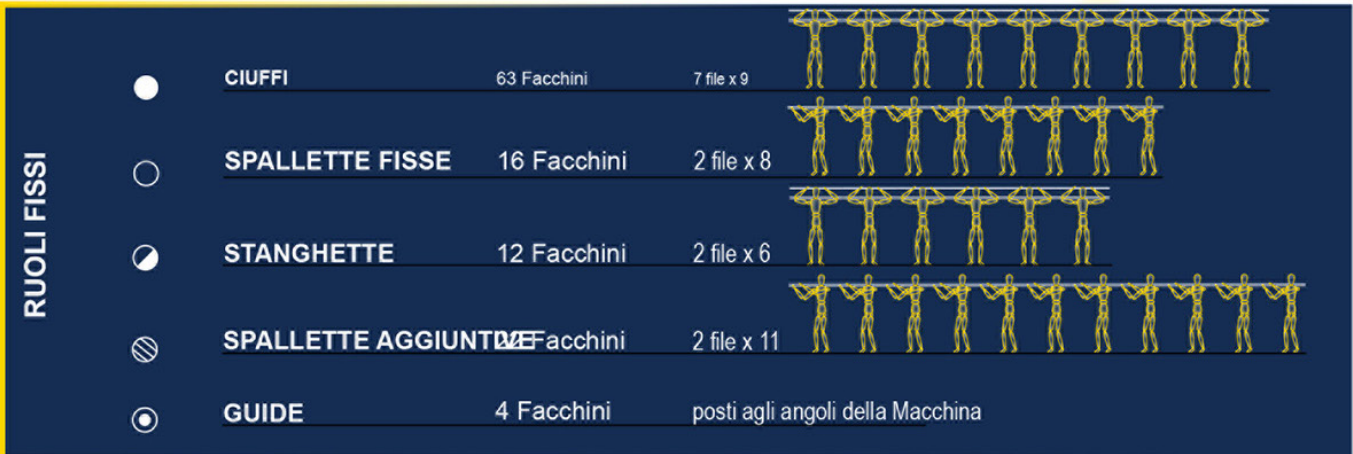

\begin{tabular}{|c|c|c|c|c|}
\hline \multirow{3}{*}{ 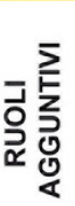 } & 当 & LEVE & 20 Facchini & $\begin{array}{l}\text { spingono sulle } 4 \text { travi inserite nella parte posteriore della Macchina } \\
\text { per il tratto finale del percorso }\end{array}$ \\
\hline & \multirow[t]{2}{*}{ (2) } & CORDE & numero varis & $\begin{array}{l}\text { tirano } 2 \text { corde agganciate alla parte anteriore della Macchina per } \\
\text { i) tratto finale del percorso }\end{array}$ \\
\hline & & CAVALLETTI & 8 Facchini & $\begin{array}{l}\text { addetti al posizionamento dei supporti posizionati sotto la base } \\
\text { della Macchina }\end{array}$ \\
\hline
\end{tabular}

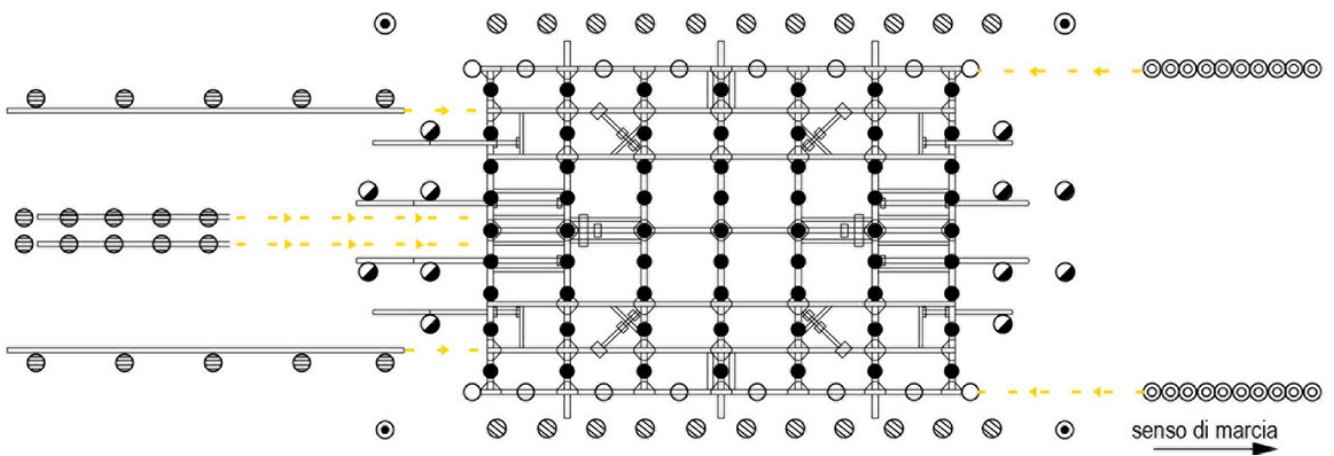


An important aspect for the fruition of this event can be referred to the synchronic and diachronic reading of the activities that take place on the Web, during the live event, through Social platforms, such as Flickr and Instagram, that amplify the perception, sharing and distribution of the urban performance; the result of these investigations includes the analysis of the images produced by the live streaming broadcasting, that provided interesting visuals from drone, taken during the nocturnal phases of the event (fig. 9).

Interesting, as well, the mobile-photography experiment put in place in recent years by the department DISUCOM of University of Tuscia, that has its results in a graphic project with an explicit referment to the Instagram semantic - social platform used by the authors themselves to share their shots- that follows two narrative complementary paths that relate to people and things, to architecture, to the city, to the environment [Fiorentino 2017].

\section{Conclusions. Providing an atmosphere, a vision}

The historical city of Viterbo, discretized and described in these brief notes, is evoked by a representation that intentionally prioritizes a planar bidimensional drawing, constantly referring to the processional shoulder-borne structure, portrayed through original project drawings, kept by the archive of municipal institutions, that as is known, are renewed every five years with a public contest. [Salucci 20 I8].

In the elaborations in the margin of this article -a significant part of this phase of the research work- the urban facades that define the spatial limits of the urban performance, are, one might say, 'dotted' with figures -inhabitants, worshippers, both resident and passing bythat follow from several points of view the passage of the parade of lights, sounds, masses. The goal is to provide an atmosphere, a vision. The spatial information are referred to the

Fig. 9.Viterbo and the urban space of the event: survey of the emotional involvement The places involved in the places sportation represenby partion represented by parallel projection simulating the live event through direct attendance. Below: trailer of the main frames of the event captured directly by the authors and by the live streaming broadcasting of the event: <https:// www.youtube.com/ watch? $=\mathrm{HH}$ bUkl.jplwg $>$ aerial view of the girat in Piazza del Plebiscito (photographs by D. Petrillo Septem 2018, night).
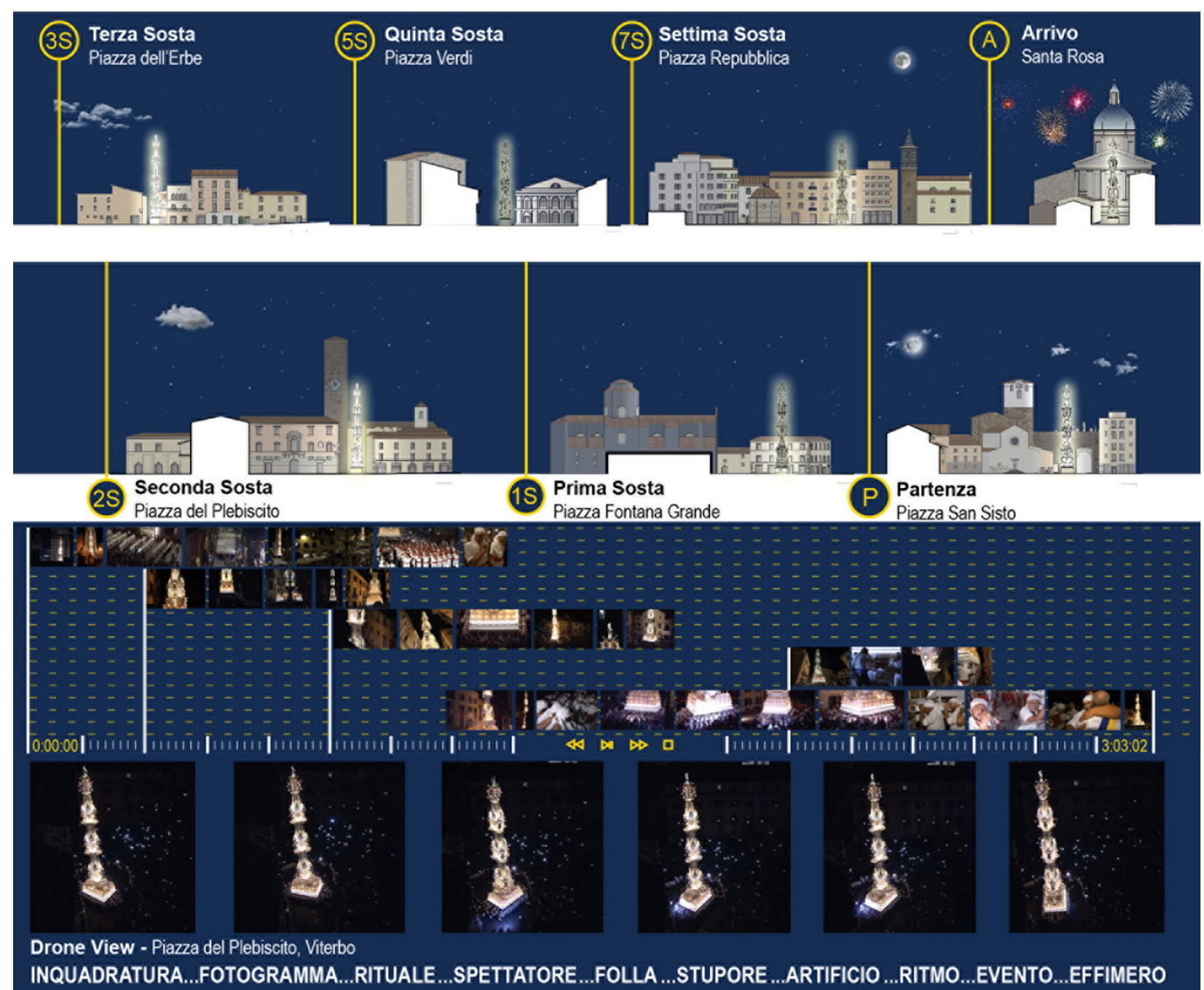
Fig. 10 Viterbo and the urban space of the event survey of the emotional involvement. Storytelling of the live event: Septem ber 3,2019. Mosaic of relevant images, collected during the preliminary ritual named Giro delle Sette Chiese. In the early afternoon of September 3 , the Porters reach on foot the first step, the Duomo of San Lorenzo, where they receive tho rretings of the autho tesing (ies, than they reach the second step, the Church of Santa Glacinta, where they recieve a symbolic eaf with a thorn, to protect them during the transportation. Once they reach Santa Maria Nuova, third step, they pose a crown at the Sacrario, going then in Piazza del Plebiscito to the Church of Sant'Angelo in Spatha fourth step; they reach the Porters' Monumentum: then (n) May go to Chiesa della Trinita, fifth step, and the Basilica di San Francesco alla Rocca. From there, they go the Convento of the Cappuccini's wood, where they meet their families. The Porters go up to the Church of Santa Rosa, seventh step, and then the Church of San Sisto, final step, where they get the In Articulo Mortis benediction, and where the Tower awaits for them (photographs or 3,2019 , day) architectonical qualities of a well-known priceless historical material heritage - belonging to the city of Viterbo, where devotional rituals for the Patron of the city are celebrated for centuries - as well as to the narration of the emotional involvement provoked by the complex system of activities that gravitates around this event.

During this process of analysis based on an intangible UNESCO heritage, Photography both oriented towards the documentation and the survey-covers all research fields and supports, on several degrees - measurement, documentation, sharing- the work of the architect: privileged observer of a performance that stands as a mediator between space and identity of a place, expression of an indispensable and necessary 'connection' between earth and sky $[\mathrm{l}]$.
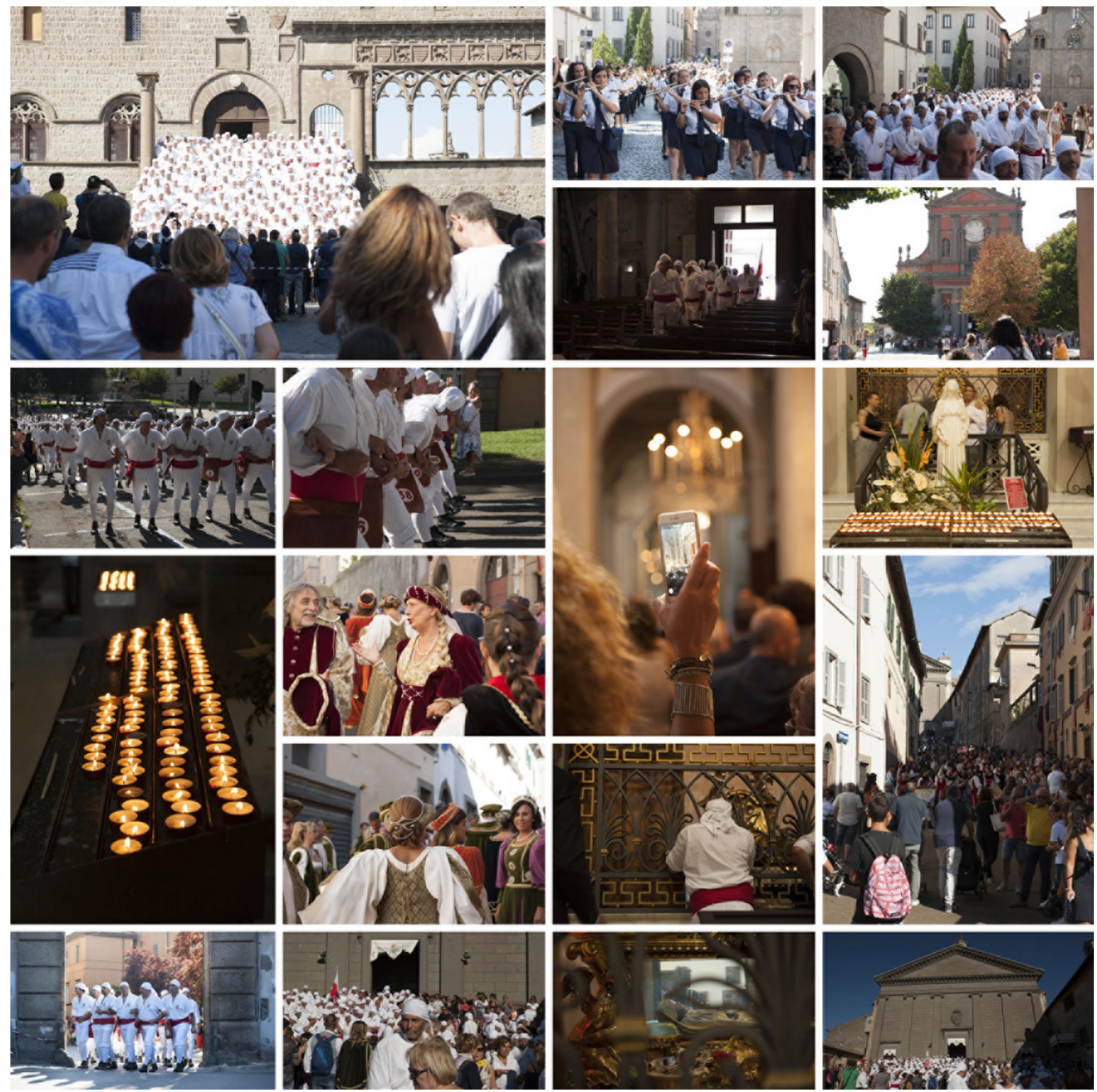

Notes

[I]This paper is the result of a common discussion and elaboration between the authors Antonella Salucci (Premise, Paragraph 3, Conclusions) and Donatella Petrillo (Paragraphs 1, 2). The original photographic documentation and elaborations are edited by the authors.

\section{References}

Bentivoglio Enzo (20 I 6). II Giubileo del 1450 e il culto di Santa Rosa, L'arrivo del Rinascimento a Viterbo e la Chiesa di Santa Rosa. Roma: GBEditoriA

Bentivoglio Enzo (20 I 7). I progetti del "Tempio di Santa Rosa" a Viterbo di Arnaldo Foschini (1 908) e le tarde idee di completamento dai suoi inediti schizzi (1967). Roma: GB Editori. 
Bentivoglio Enzo, Valtieri Simonetta (2012). Viterbo nel Rinascimento. Roma: GBEditoriA.

Falcioni Giorgio (200 I). La Macchina di Santa Rosa. Memorie, feste, curiosità, folclore, culto, protagonisti.Viterbo: Agnesotti Editore.

Fiorentino Giovanni (2017).Viterbo, la fotografia e la vita quotidiana. I colori (e gli occhi) di Santa Rosa. In Santa Rosa, le persone le cose. Santa Rosa, le cose, le persone. II bianco e il rosso.Volume 2 DISUCOM. Università degli Studi della Tuscia, pp. 3-7. Viterbo Edizioni Sette Città.

Koolhass Rem (2014). Fundamentals. Architettura non Architetti. Monditalia. La Biennale di Venezia, $14^{a}$ Mostra Internazionale di Architettura Venezia 20 14. Catalogo della mostra. Venezia: Marsilio.

Nardi Patrizia (20|4). Patrimonio del Cuore, Patrimonio dell'Umanità UNESCO. Le Feste e la Rete. In I Beni Culturali. Tutela, valorizzazione, attività culturali, architettura contemporanea, bioarchitettura e turismo. Speciale Macchina di Santa Rosa da Viterbo Patrimonio UNESCO, numero 2, anno XXII, Maggio-agosto 2014, pp. 83-96. Viterbo: BetaGamma Editrice.

Parlato Enrico (2002). La processione di Santa Rosa a Viterbo: dall'iconografia quattrocentesca alle macchine barocche. In Fagiolo Marcello. Atlante Tematico del Barocco in Italia. II "Gran Teatro" del Barocco. Le capitali della festa. Roma: De Luca Editori d'Arte, pp. 25 I-260.

Salucci Antonella (2016). The urban space of the ephemeral heritage. Celebrations of big shoulder-borne processional structures. In Gambardella Carmine (ed.). World Heritage and Degradation. Smart Design, Planning and Technologies. XIV International Forum "Le vie dei Mercanti", Naples and Capri, I6/I 8 June 20 I6, pp. I207-I2 I4. Napoli: La scuola di Pitagora Editrice.

Salucci Antonella (20I8). Comunicazione e Valorizzazione del Patrimonio Immateriale Unesco. II Trasporto della Macchina di Santa Rosa da Viterbo, Italia. In Salerno Rossella (a cura di). Rappresentazione/Materiale/lmmateriale. Drawing as (in)tangible representation. $40^{\circ}$ Convegno Internazionale dei Docenti delle Discipline della Rappresentazione XV UID Congresso della Unione Italiana per il Disegno, Milano I 3- 5 settembre. Roma: Gangemi Editore, pp. I 402-I4I2.

Trione Vincenzo (20।4). Effetto città. Arte cinema modernità. Roma: Bompiani.

Unali Maurizio (20 I0).Architettura Effimera. <http://www.treccani.it/enciclopedia/architettura-effimera_\%28XXI-Secolo\%29/>.

Unali Maurizio (20I5). Rappresentare l'immateriale. Cultural heritage e poetiche dell'effimero / Representing the intangible Cultural Heritage and the Poetics of the Ephemeral. In Giovannini Massimo, Arena Marinella, Raffa Paola (a cura di). Spazi e Culture del Mediterraneo. Ricerca Prin 2009-20 I I. Napoli: La scuola di Pitagora, Pp. I027- 104 I.

UNESCO Rete delle Grandi Macchine a Spalla Italiane: <https://ich.unesco.org/en/RL/celebrations-of-big-shoulder-borneprocessional-structures-0072I>.

Valtieri Simonetta (20 I7). Viterbo e i Giubilei del Rinascimento (I 450-1550). Storia, personaggi, opere. Roma: GBEditoriA.

\section{Authors}

Antonella Salucci, Università degli Studi “Gabriele d'Annunzio" di Chieti-Pescara, antonella.salucci@unich.it Donatella Petrillo, Università degli Studi "Gabriele d'Annunzio" di Chieti-Pescara, donatellapetrillo@gmail.com

To cite this chapter. Salucci Antonella, Petrillo Donatella (2020). Connessioni tra terra e cielo. Forma e immagine nel racconto delle qualità intangibili di uno spazio urbano/Connections between earth and sky. Shape and image in the representation of the intangible qualities of an urban space. In Arena A., Arena M., Brandolino R.G., Colistra D., Ginex G., Mediati D., Nucifora S., Raffa P. (a cura di). Connettere. Un disegno per annodare e tessere. Atti del $42^{\circ}$ Convegno Internazionale dei Docenti delle Discipline della Rappresentazione/Connecting. Drawing for weaving relationships. Proceedings of the 42th International Conference of Representation Disciplines Teachers. Milano: FrancoAngeli, pp. 3774-3799. 